\title{
PROCLAIMING THE FUTURE: HISTORY AND THEOLOGY IN PROPHeCIES AgAINST TyRE
}

\author{
Thomas Renz
}

\begin{abstract}
Summary
This essay seeks to contribute to our understanding of the nature and function of predictive prophecy. On the basis of programmatic statements in Isaiah 40-55 and a careful analysis and comparison of prophecies against Tyre in Isaiah 23 and Ezekiel 26 that takes into account the actual history of Tyre, other prophetic references to Tyre, and the theological thrust of the relevant sections, it is argued that predictions are an essential part of the prophetic message. Yet they offer a paradigmatic picture of God's dealings with his people and the nations rather than a detailed outline of future events. Thus prophetic predictions are not historiography before the event but a proclamation of God's purpose. This explains the conventional and vague language of many predictions, the element of conditionality in biblical prophecy, and the selective nature of the vision of the future being offered.
\end{abstract}

\section{Introduction}

There are today those who demand that we 'change the dialogue partner of biblical exegesis from history to theology'.1 While in sympathy with the concern expressed in this demand, I believe the dichotomy presupposed is misguided. Responsible biblical exegesis is done in dialogue with both history and theology. The purpose of this paper is to engage in serious historical research for the benefit of a more adequate biblical theology of the nature of prophecy. The paper develops a thesis about the role of the predictive element in prophecy based on statements in Isaiah 40-55 and then takes prophecies against Tyre as a test case. In this way, I hope to rise

1 The phrase is from C. Rowland, 'An Open Letter to Francis Watson on Text. Church and World', SJT 48 (1995), 512. 
above the inductive/deductive dichotomy that often characterises discussions about the nature of Scripture. Tyre has been chosen because it plays a prominent role in biblical prophecy but the number of prophecies related to it is not so overwhelming as to make a project such as this unmanageable.

\section{Proclaiming the future}

\section{Introduction: Foretelling and forthtelling}

It is generally agreed that the prophetic message consists of proclamation and prediction. The time when it was fashionable to minimise the predictive element of prophecy in favour of a strong emphasis on the prophets as spokesmen of God seems to be gone and a more healthy balance is struck between the predictive and the non-predictive side of prophecy, between foretelling and forthtelling. ${ }^{2}$ Yet the relationship between proclamation and prediction is often left undefined. This paper focuses on the nature and function of prophetic predictions and argues that prediction is a form of proclamation. No full biblical theology of the role of predictions is presented here. Before this can be done, more attention needs to be given to narrative and apocalyptic literature including New Testament prophecy in addition to the exploration of the prophetic literature in this paper. ${ }^{3}$

The extent of prediction in the Old Testament is debated. Often the prophets proclaim God's condemnation of sin by predicting coming judgement on sin. The same goes for the prophetic use of laments and other genres. Since the prophecy of punishment is probably the most common speech form employed by pre-exilic prophets, the extent of predictions is actually much larger than is often realised. It is only by limiting the count to long-range predictions that the extent of the predictive element in prophecy becomes comparatively small.

2 Note W.F. Albright's admission in the introduction to the second edition of his From the Stone Age to Christianity: Monotheism and the Historical Process (Garden City, NY: Doubleday Anchor Books, 1956), 17, that he along with the majority of biblical scholars had underestimated the predictive element of prophecy in the 1940s.

3 See J.J. Roberts, 'A Christian Perspective on Prophetic Prediction', Interpretation 33 (1979), 240-53. 
There are principally three ways by which prophets in the ancient Near East predicted the future: through logical deduction, intuitive prophecy, and technical prophecy (divination, omens). ${ }^{4}$ Among these the last one in particular might suggest that what is sought is a preview of the future which already exists in some form. Yet, as Cryer noted, 'for practically every portent of ill-omen which the omen series could produce there existed either general or specific remedies which the exorcist/conjurer might use' ${ }^{5}$ In other words, the 'future' that was 'discovered' through technical prophecy could still be nullified by apotropaic incantations. In any case, divination was forbidden to the Israelites as a way to discern the future (see e.g. Dt. 18:9-14). ${ }^{6}$ Instead, God promised to raise up prophets who would continue to mediate God's words to his people as Moses had done (Dt. 18:15-20; cf. 5:22-33). The key difference between legitimate and illegitimate prophecy was however not formal. Loyalty to the covenant God was the first criterion of true prophecy (cf. Dt. 13:1-6). The prophetic word had to be in agreement with the word of Yahweh already revealed. In addition, it was assumed that when a genuine prophet predicted the future the prediction would always come to pass, although this might become clear only over the course of time. ${ }^{7}$ According to Deuteronomy 18, prediction is part of the prophetic conveying of God's word. It needs to come true because, as Isaiah 40 emphasises, 'the word of our God will stand forever' (v. 8b). My understanding of the relationship between prediction and

4 Egyptian 'prophecies' do not claim to be more than extrapolation from the present to the future. Mantic techniques were highly developed in Mesopotamia (cf. Ezk. 21:26ff. [ET 21:21ff.]; Is. 47:12-13; Dn. 5:11) and fulfilled many functions, of which discerning the future was only one. Examples of intuitive prophecy are found at Mari where however such inspirations were often verified by technical prophecy.

5 F.C. Cryer, Divination in Ancient Israel and Its Near Eastern Environment: A Socio-historical Investigation (JSOTSS 142; Sheffield: JSOT Press, 1994), 210.

6 This is not to say that divination did not exist in ancient Israel (see Je. 27:9 for predictive divination). Some forms were even sanctioned in the Pentateuch, but not for the discernment of the future. For a fuller discussion see Cryer, Divination, 229-305; cf. H.B. Huffmon, 'Priestly Divination in Israel', in C.L. Meyers and M. O'Connor (eds.), The Word of the Lord Shall Go Forth: Essays in Honor of David Noel Freedman in Celebration of His Sixtieth Birthday (ASOR Special Volume Series 1; Winona Lake, IN: Eisenbrauns, 1983), 355-59. 7 The principle is evident in 1-2 Kings, see esp. I Ki. 14:1-16/15:27-30; 16:1-4/16:11-14; 21:20-24/22:37-38 (but see $21: 27-29$ ); $2 \mathrm{Ki} .1: 2-4,6 / 1: 17$ 18: $2 \mathrm{Ki} .9: 36-37 / 10: 17$; cf. $1 \mathrm{Ki} .13: 1-10 / 2 \mathrm{Ki} .23: 15-18$. The classic study of this prophecy-fulfilment correlation is in G. von Rad, "The Deuteronomic Theology of History in I and II Kings', in The Problem of the Hexateuch and Other Essays (Edinburgh and London: Oliver \& Boyd, 1966), 205-221. 
proclamation is shaped by my reading of the programmatic statements in Isaiah 40-55 to which we will turn before formulating a thesis on the role of prediction in biblical prophecy.

Isaiah 41:21-29 describes a court scene in which Yahweh presents a challenge to (presumably Babylonian) idol-gods regarding their ability to explain the past and to declare the future. Knowledge of the future is linked both to a right understanding of the past (v. 22) and to the power to accomplish things (vv. 23-24). Yahweh alone was able to announce beforehand the rise of Cyrus (v. 26), because he was the one who stirred up Cyrus (v. 25). The idol-gods are a delusion 'because their works are nothing' (v. 29; cf. v. 24). They cannot predict the future because they neither understand the past nor have the power to do something which they could announce beforehand. A similar challenge is issued in 43:8-13, now with a greater emphasis on Yahweh's power to deliver his people which leads to a speech that asks Israel to consider the 'new thing' that the God who created them is about to do (43:14-21). The new thing is said to 'spring forth' (v. 19b; cf. 42:9), but there can be no doubt about who makes these things spring forth: 'I am about to do a new thing...I will make a way in the wilderness and rivers in the desert' (v. 18a, 19). Again the emphasis is not on God's ability to let his people know beforehand what would happen, but on his power to change world history for the sake of his people. The ability to announce this act beforehand reveals who is behind the event (rather like the terrorist organisation that proves it has 'planted' a bomb by letting it be known beforehand where it will explode-if this comparison may be allowed). This ability is unique evidence of Yahweh's divinity (cf. 44:6-8). As creator God who has a purpose for Jerusalem, he is able to frustrate 'the omens of the liars' and to confirm 'the word of his servant' and fulfil 'the prediction of his messengers' (44:24-28; cf. 47:9 for a similar emphasis on God's ability to overcome Babylonian 'sorceries'). The question is not s o much who has the better discernment of the future, but who has the greater power to shape the future. Yahweh claims that he is the only one who can determine what happens (45:5-8; cf. v. 21). In words from Isaiah 46 and 48 ,

I am God, and there is no one like me, declaring the end from the beginning and from ancient times things not yet done, saying, "My purpose shall stand, and I will fulfil my intention,'...I have spoken, and I will bring it to pass; I have planned, and I will do it (46:9ba-10, IIb).

The former things I declared long ago, they went out from my mouth and $I$ made them known; then suddenly I did them and they came to 
pass...I declared them to you from long ago, before they came to pass I announced them to you, so that you would not say, 'My idol did them, my carved image and my cast image commanded them' $(48: 3,5)$.

To sum up our review of Deuteronomy 18 and Isaiah 40-55, it is evident that no means of determining the future were allowed to the Israelites that bypassed the initiative of their covenant God. Proper knowledge to be sought is the word which Yahweh gives through his prophets and which may or may not encompass future events. Because Yahweh desires to be known by his people as the author of certain events, he announces his purpose beforehand. A true prophet of the covenant God is recognised by the fact that his description of God's purpose stands and proves true over the course of time. This brings us to a definition of the place of the predictive element in biblical prophecy.

\section{Thesis: The place of foretelling in biblical prophecy}

A prophetic prediction rests on the claim to have stood in the council of God rather than the claim to have travelled into the future. ${ }^{8}$ It is a claim of having insight into God's plan rather than of having had a preview of the future. Yahweh revealed what he was going to do rather than simply what was going to happen. He is praised not for his passive foreknowledge of events, but his active intervention to bring about his purpose. The fulfilment of things previously announced is not so much a proof of Yahweh's knowledge but of his sovereignty in historical events. The declaration beforehand is proof that Yahweh was at work rather than any idol (48:5). Prediction is thus an integral and prominent part of the proclamation of what God's purposes are and how he will accomplish them. Our modern antithesis between foretelling and forthtelling seems rather artificial and may be the result of an

8 M.E. Polley, 'Hebrew Prophecy within the Council of Yahweh, Examined in Its Ancient Near Eastern Setting', in C.D. Evans et al. (eds.), Scripture in Context: Essays on the Comparative Method (PTMS 34; Pittsburgh, PN: Pickwick, 1980), 141-45, argued that the concept of Yahweh's council, while not mentioned very frequently in the prophetic literature, is nevertheless the proper setting for the messenger formula and the lawsuit motif in the prophets. R.P. Gordon, 'From Mari to Moses: Prophecy at Mari and in Ancient Israel', in H.A. McKay and D.J.A. Clines, Of Prophets' Visions and the Wisdom of Sages: Essays in Honour of R. Norman Whybray on His Seventieth Birthday (JSOTSS 162; Sheffield: JSOT Press, 1993), 63-79, argues that at Mari both prophecy and divination are linked with access to the divine council; cf. his "Where Have All the Prophets Gone? The "Disappearing" Israelite Prophet against the Background of Ancient Near Eastern Prophecy', BBR 5 (1995), 67-86, esp. pp. 78-80. 
understanding of prediction that makes it more akin to prognostication than proclamation.

\section{Tyre in history and prophecy}

\section{Background: The history of Tyre during the era of the prophets ${ }^{9}$}

Tyre is a city of great antiquity. It was built on an island and may have been a daughter city of Sidon, although it was involved in continuous strife with Sidon in the Amarna age.10 It was an important seaport on the eastern Mediterranean coast from about $1200 \mathrm{BC}$ onwards at the latest, but witnessed its first golden age under Hiram I (969-936 BC), at the same time as the Davidic empire was established. ${ }^{11}$ With Ugarit having been completely destroyed at the beginning of the twelfth century, Tyre became the major port of the Eastern Mediterranean. Its predominance over Phoenicia led even to the incorporation of Sidon into the kingdom of Tyre for a while during part of the Neo-Assyrian period, although the two were later divided again into separate kingdoms.

Together with other coastal cities Tyre played a key role in the economic system of the ancient Near East (cf. Ezk. 27). Trading operations between the large centres of power and influence, Egypt, the Hittite realm, and Assyria or Babylonia, seem to have been

9 See esp. N. Jidejian, Tyre through the Ages (Beirut: Dar El-Mashreq, 1969); H.J. Katzenstein, The History of Tyre: From the Beginning of the Second Millennium B.C.E. until the Fall of the Neo-Babylonian Empire in 538 B.C.E. (Jerusalem: Schocken, 1973), and 'Tyre in the Early Persian Period (539-486 B.C.E.)', BA 42 (1979), 23-34. Cf. S. Moscati, The World of the Phoenicians (London: Weidenfeld and Nicolson, 1968), 8-29; J. Elayi, "The Phoenician Cities in the Persian Period', JANESCU 12 (1980), 13-28, and 'Studies in Phoenician Geography during the Persian Period', JNES 41 (1982), 83-110; W. Culican, 'Phoenicia and Phoenician Colonization', in the Cambridge Ancient History, second edition, vol. III, part 2 (CAH2 III, 2): The Assyrian and Babylonian Empires and Other States of the Near East, from the Eighth to the Sixth Centuries B.C. (Cambridge: CUP, 1991), 461-546; V. Krings (ed.), La civilisation phonicienne et punique: Manuel de recherche (Handbook of Oriental Studies, section 1: The Near and Middle East, vol. 20; Leiden: Brill, 1995); A. Kuhrt, The Ancient Near East c. 3000-330 BC (London and New York: Routledge, 1995), 2:402-410.

10 See L. Badre, 'Canaanite Tyre', in M. Sharp Joukowsky (ed.), The Heritage of Tyre: Essays on the History, Archaeology, and Preservation of Tyre (Dubuque, IA: Kendall/Hunt, 1992), 37-42.

11 Cf. A.R. Green, 'David's Relations with Hiram: Biblical and Josephan Evidence for Tyrian Chronology', in Meyers and O'Connor, The Word of the Lord Shall Go Forth, 373-97. 
conducted mostly via the Phoenician cities. They themselves concentrated their efforts on the production of luxury commodities (textiles, metal work, ivory and wood carving) as well as perfecting the building and navigation of ships. ${ }^{12}$ The city of Tyre was ruled by kings whose power was probably limited by priests and merchants. ${ }^{13}$ From the ninth century onwards Assyrian pressure was increasingly felt throughout Syria-Palestine. Ashur-nasirpal II (884-858 BC) led an expedition to Carchemish and the Lebanon in 877 BC to collect tribute from Tyre, Sidon and Byblos among others, 14 but the aim of the campaign was probably more of a commercial rather than military nature. ${ }^{15}$ His son and successor Shalmaneser III (858-824 BC) was determined to get a firmer grip on north Syria. He was stopped at Qarqar in $853 \mathrm{BC}$ but successfully collected tribute from Damascus, Israel, Tyre and Sidon in $841 \mathrm{BC} .{ }^{16}$ The records for the following century are somewhat patchy and do not allow us to draw a picture with much confidence, yet there seem to have been times of Assyrian dominance as well as (relative) Phoenician independence. ${ }^{17}$ As S. Moscati comments, 'Assyrian expansion had not taken the form of lasting conquest in Phoenicia so much as control from a distance and imposition of tributes.' 18 This changed with TiglathPileser III (745-727 BC), who brought Syria-Palestine more or less under Assyrian dominance, incorporating most of it into the Assyrian provincial system and setting up six governors who were

12 See e.g. Frankenstein, 'Phoenicians in the Far West: A Function of NeoAssyrian Imperialism', in M.T. Larsen (ed.), Power and Propaganda: A Symposium on Ancient Empires (Mesopotamia 7; Copenhagen: Akademisk Forlag, 1979), 263-94. Elayi points out that at least in the Persian period the Phoenicians also developed considerable skill in warfare, 'Cities', 18.

13 Cf. P.M. Bikai, 'Phoenician Tyre', in Joukowsky, Heritage, 45-53.

14 See the annals inscribed on pavement slabs of the temple of Ninurta in Calah built by the king (ANET 275-76).

15 Cf. Jidejian, Tyre, 42; Moscati, World, 16.

16 See the epigraphs collected in ANET 281. It seems however that Tyre was not part of the anti-Assyrian forces in $853 \mathrm{BC}$; see J.H. Hayes, Amos-The Eight Century Prophet: His Times and His Preaching (Nashville: Abingdon, 1988), 89.

17 Katzenstein thinks that 'with the death of Shalmaneser III in 824 B.C., Tyre was free from paying tribute to Assyria' ('Tyre', $A B D$ 6:689), and Moscati speaks of 'several decades' of 'relative tranquillity' (World, 17). Adadnirari III (810-782 BC) was able to collect tribute from north-west Syria; see the inscription found at Calah (ANET 281-82) and the Sabaia Stela (ANET 282 ). The latter indicates however that tribute had been denied to his father Shamshi-Adad V.

18 Moscati, World, 18. Cf. B. Oded, 'The Phoenician Cities and the Assyrian Empire in the Time of Tiglath-pileser III', ZDPV 90 (1974), 38-48, pp. 38-4I. 
directly responsible to the Assyrian king. 19 Hiram of Tyre submitted to Tiglath-Pileser III but Tyre was not incorporated into the Assyrian provincial system and was able to retain some form of partial independence, probably because the island-city itself had not been conquered. ${ }^{20}$ The stability brought to the region through TiglathPileser III apparently led to an intensification of commercial activities and the Phoenician cities succeeded in linking previously separate trading spheres. ${ }^{21}$ Yet the creation of Phoenician colonies around the Mediterranean world, most famous among them Carthage, might have been inspired partly by Tyre's difficulties in holding its mainland possessions against the Assyrians. ${ }^{22}$

There were several Phoenician attempts to shake off the yoke of Assyria to which Shalmaneser V (727-722 BC) and Sargon II (721-705 $\mathrm{BC})$ responded by occupying the mainland of Tyre, thereby cutting off some of Tyre's water supply $(725-720 \mathrm{BC}){ }^{23}$ Sargon also took possession of Cyprus. ${ }^{24}$ As a consequence, 'the Phoenicians were no longer able to retain sole control of the trade routes and fell under the aegis of greater powers' ${ }^{25}$ Yet both were unable to conquer Tyre itself. After the death of Sargon, the Phoenicians again refused to

19 See the annalistic records found in Calah (ANET 283). For a discussion of Tiglath-Pileser III's campaigns, see S.A. Irvine, Isaiah, Ahaz, and the SyroEphraimitic Crisis (SBLDS 123; Atlanta, GA: Scholars Press, 1990), 23-72; and G. Galil, The Chronology of the Kings of Israel \& Judah (Leiden: Brill, 1996), 68-70.

20 For details, see Oded, 'Phoenician Cities', pp. 46-47, and M. Elat, 'The Political Status of the Kingdom of Judah within the Assyrian Empire in the 7th Century B.C.E.', in Y. Aharoni (ed.), Lachish V-Investigations at Lachish: The Sanctuary and the Residency (Tel Aviv: Gateway Publishers, 1975), 6170, esp. pp. 64-65; cf. Moscati, World, 19.

21 Kuhrt, Ancient, 2:410, points out that the Phoenician alphabet and the designation 'Phoenician' were not used exclusively by or with reference to inhabitants of the Phoenician cities which leaves us with some uncertainty about the extent of 'Phoenician' influence. Yet there can be little doubt about the success of Tyre's trade overseas in the Assyrian period.

22 As M. Liverani suggests, 'Tyre', ISBE 4:934.

23 According to Josephus, Antiquities 9.14.2 (283-87), Menander credited Shalmaneser with a five year siege of Tyre, but it is more likely that Shalmaneser's effort was continued by Sargon. No Assyrian historical texts from Shalmaneser's short reign seem to have been recovered.

24 See the Cyprus (or Larnaka) Stela (ANET 284) which was found in the ruins of Citium, the main Phoenician city on the island. Cf. V. Karageorghis, 'Cyprus', in $\mathrm{CAH}^{2}$ III, 1: The Prehistory of the Balkans; and the Middle East and the Aegean World, Tenth to Eight Centuries B.C. (Cambridge: CUP, 1982), 511-33, p. 533, and idem, 'Cyprus', in $C A H^{2}$ III, 3: The Expansion of the Greek World, Eight to Sixth Centuries B.C. (Cambridge: CUP, 1982), 57-70, esp. p. 57.

25 Moscati, World, 19. 
pay their tribute. Sennacherib (704-681 BC) conquered Sidon and the mainland territories, forced king Eloulaios to retreat to Cyprus, and broke up the kingdom of Tyre installing an independent king in Sidon $(701 \mathrm{BC})$. His failure to mention Tyre in his lists of conquests indicates that Sennacherib was unable to subjugate Tyre itself,26 which remained a strong power on the Phoenician coast. His successor Esarhaddon (681-669 BC) drew up a treaty with the Tyrian king Baal ( $\mathrm{Ba}^{\mathrm{C} l \mathrm{lu}}$ ) which specified the ports of trade on the Palestinian coast and the trade routes to which Tyre was allowed access and carefully regulated what was to happen when a Tyrian ship stranded.27 Presumably because they were dissatisfied with the conditions of the treaty, the Tyrians rebelled against Assyria. Esarhaddon responded by capturing Tyre's mainland territory and besieging Tyre on his second campaign against Egypt in $671 \mathrm{BC}$. He was however unable to take the island-city. ${ }^{28}$ Ashur-banipal (669-633 BC) similarly boasted that he made the king of Tyre submit to him, ${ }^{29}$ although he too only conquered the continental city of Tyre (Ushu). ${ }^{30}$ The conquest of Tyre's mainland territory allowed the Assyrians to exercise some control over Tyre by blocking its supply routes from the mainland. The Assyrians could hardly have been interested in completely destroying this important commercial centre.

\footnotetext{
26 See the Annals of Sennacherib (ANET 287-88).

27 The treaty is published in English translation in ANET 533-34. See also the relevant section in Esarhaddon's annals (Prism B, col. II, lines 27-30, and Prism S, col. III, lines 5-25), published in D.D. Luckenbill, Ancient Records of Assyria and Babylonia (2 vols.; Chicago: University of Chicago Press, 192627 ), vol. II, par. 511-12, and a stone slab inscription published there under par. 710 (the latter also in ANET 290).

28 See the description of the Syro-Palestinian campaign from the Prism A (ANET 290-91) and of the campaign against the Arabs and Egypt from the Prism B (ANET 291-93). Sidon was captured in Esarhaddon's fourth year and its king decapitated a year later, see A.K. Grayson, Assyrian and Babylonian Chronicles, Locust Valley, NY: Augustin, 1975), Chronicle 1 (preserved in three copies: BM 92502, BM 75976, BM 75977) iv 3-8 on p. 83, cf. the Chronicle 14.12-14 (the Esarhaddon Chronicle preserved on BM 25091, regarded as less reliable because obviously biased) on p. 126 .

29 See the Rassam Cylinder ii (ANET 295-96; cf. Cylinder C i 24-46 in ANET 294), the Warka Cylinder and an inscription found in the temple of Ishtar (both in ANET 297).

30 See the Rassam Cylinder ix (ANET 299-300). Ushu was an important source of fresh water for Tyre and also the location of Tyre's necropolis. The references to the 'city of the fortress of Tyre' in Joshua 19:29 (and the 'fortress of Tyre' in $2 \mathrm{Sa}$. 24:7) might be to Ushu rather than Tyre, but the issue is notoriously difficult to decide; see Z. Kallai, Historical Geography of the Bible: The Tribal Territories of Israel (Jerusalem: Magnes Press; Leiden: Brill, 1986), 215-20.
} 
To benefit from Tyre's wealth, the island-city had to be allowed to function as a commercial centre. ${ }^{31}$ Thus Tyre's island position on the one hand made it attractive to the Assyrians, but on the other hand allowed it to remain still fairly autonomous even up to the collapse of the Assyrian empire brought about by the Medes and Babylonians. Nevertheless, the city must have benefited from the dissolution of the Assyrian empire and having regained its former possessions on the mainland probably experienced renewed prosperity. Yet Nebuchadrezzar's victory at Carchemish in $605 \mathrm{BC}$ over Egyptian forces and the defeat of Ashkelon a year later quickly changed the situation in the eastern Mediterranean and again threatened Tyre's freedom and commercial advantage. Nebuchadrezzar was unable to capture the island-city, but lifted the thirteen year siege (585-572 BC) only after Tyre's submission. ${ }^{32}$ Thus the city remained intact, but serious damage was done to its position. 'Tyre's commerce was ruined as a result of inability to conduct peaceful trade.' 33 In the long run the city lost its hegemony and leadership among the Phoenician coastal towns to Sidon.

When the Babylonian empire was taken over by the Persians, the Phoenician cities voluntarily transferred their vassalage to the Persian king. ${ }^{34}$ They were incorporated into the fifth satrapy, ${ }^{35}$ but enjoyed a certain degree of autonomy and were permitted to keep their local kings. ${ }^{36}$ Jidejian observed that throughout the Persian period 'the kings of the Phoenician city-states commanded their naval contingents and were treated as allies not as vassals' ${ }^{37}$ They

31 For an overall positive assessment of the Assyrian period from the point of view of Tyre, see Frankenstein, 'Phoenicians', and Bikai, 'Phoenician Tyre'.

32 The length of the siege is reported in Josephus, Against Apion 1.21 (156); cf. Antiquities 10.11.1 (228), but not its outcome. Seeing that the king of Tyre headed the list of foreign kings in Nebuchadrezzar's 570 BC court register (on a prism in Istanbul [No. 7834], see $A N E T$ 308), we may conclude that he had to submit. For a fuller discussion see Katzenstein, History, 325-31; cf. L.C. Allen, Ezekiel 20-48 (WBC 29; Dallas, TX: Word, 1990), 109; M. Greenberg, Ezekiel 21-37: A New Translation with Introduction and Commentary (AB 22a; New York: Doubleday, 1997), 541; D.I. Block, The Book of Ezekiel: Chapters 25-48 (Grand Rapids, MI: Eerdmans, 1998), 31. D.J. Wiseman, Nebuchadrezzar and Babylon (The Schweich Lectures 1983; Oxford: OUP, 1985), 24-29, suggests that the siege began in $603 / 2 \mathrm{BC}$.

33 Jidejian, Tyre, 59. Tyre's overseas territories were taken over by Carthage.

34 See Herodotus, The Persian Wars, 1.143.

35 See Herodotus 3.91 .

36 See Elayi, 'Cities'.

37 Jidejian, Tyre, 60-61. Cf. F.G. Maier, 'Cyprus and Phoenicia', in $C A H^{2}$ VI: The Fourth Century B.C. (Cambridge: CUP, 1994), 297-336, 717-26. 
even succeeded in calling off a campaign against Carthage by refusing to support Cambyses on this occasion. ${ }^{38}$ That the Persian king maintained a park and a royal residence in Sidon, that the Phoenician fleet was commanded by the king of Sidon, and the seating arrangements of Xerxes' war council indicate that Sidon was more important than Tyre. ${ }^{39}$ Yet people of Tyre engaged in commercial activities in Jerusalem (see Ne. 13:16) and began to mint coins in the middle of the fifth century. Jidejian suggests that the Phoenicians supported Darius enthusiastically in his attempt to incorporate Greece into his empire, as this would strike a blow to increased Greek competition. ${ }^{40}$ Apart from a conflict in about $385 \mathrm{BC}$, when Tyre and other Phoenician cities were conquered by Evagoras of Salamis, who ruled Cyprus and for a while made it nearly autonomous, ${ }^{41}$ Tyre apparently remained under Persian rule at least nominally until the rise of the Macedonians, enjoying growing autonomy and renewed prosperity. ${ }^{42}$ Archaeological findings suggest increased Phoenician expansion in the south, in particular on the coast from Haifa to 'Atlīt, but also further south (e.g. Dor, Jaffa, Ashkelon). 43

The fall of Tyre to Alexander the Great was the next major event. Unlike Arvad, Byblos and Sidon, which surrendered without a fight, Tyre refused Alexander access to the city and was besieged. Alexander destroyed Ushu and used the rubble to construct a massive causeway from the mainland to the island-city transforming it to a peninsula. After a seven-month siege and with support from Sidon and Cyprus, Alexander conquered Tyre in 332 BC. After the death of Alexander Tyre changed hands several times, so e.g. in 314 BC when the city finally capitulated to Antigonus, in 288/87 BC when Ptolemy I Soter deprived Demetrius Poliorcetes (the son of Antigonus) of Sidon and Tyre, in 219 BC when the Theodotus, commander of Acco and Tyre, surrendered to the Seleucids, and

\footnotetext{
38 See Herodotus 3.19.

39 See Diodorus Siculus 16.41.1-5; 14.67 (cf. Herodotus 7.128); Herodotus 8.67.

40 Jidejian, Tyre, 63.

41 Maier, 'Cyprus and Phoenicia', 312-17, 326; H.-P. Müller, 'Phönizien und Juda in exilisch-nachexilischer Zeit', WO 6 (1970/71), 189-204; cf. Jidejian, Tyre, 65-66. The revolt and defeat of the Sidonian king Tennes around forty years later seems to have had little impact on Tyre.

42 Cf. Maier, 'Cyprus and Phoenicia', 320-24.

+3 See esp. Müller, 'Phönizien', 195-98; cf. Maier, 'Cyprus and Phoenicia', 321 .
} 
again in $217 \mathrm{BC}$ when Antiochus III lost the region to Ptolemy V Epiphanes. ${ }^{44}$ In economic terms, it appears to have recovered remarkably well from the defeat at the hands of Alexander without (at first) suffering too greatly from competition with Alexandria. 'Any lost trade opportunities were more than compensated for by new commercial advantages resulting from Seleucid control in the east and the security which was essential for trade expansion.'45 However, when Ptolemy II Philadelphus redirected Red Sea and Indian trade from the Petra-Tyre route to Alexandria, Tyre suffered a great loss. It regained importance during the Roman period being famous for its silk products, glass ware and a purple dye extracted from local sea snails of the genus Murex. ${ }^{46}$ Purple dye has been called 'the most enduring status symbol of the ancient world' 47 While Tyre was not the only place to provide purple dye, 48 its exorbitant price must have made it a lucrative trade. Tyre's harbour kept its strategic importance until the time of the Crusades. ${ }^{49}$

\section{Overview: Tyre in biblical prophecy}

The overview briefly discusses all references to Tyre in biblical prophecy, before Isaiah 23 and oracles from Ezekiel are discussed in more detail. Tyre is accused in Amos 1:9-10 of delivering an entire community to Edom, even one with which it was in a covenant relationship. The charge echoes that against the Philistines, who are similarly accused of handing over an entire community to Edom (1:6). ${ }^{50}$ It is noteworthy 'that the two nations located on the

44 See references to Tyre in $C A H^{2}$ VII, 1: The Hellenistic World (Cambridge: CUP, 1984).

45 Jidejian, Tyre, 81.

46 D.R. Edwards, 'Tyre (in the Greco-Roman Period)', $A B D$ 6:690-91.

47 M. Reinhold, History of Purple as a Status Symbol in Antiquity (Collection Latomus 116; Brussels: Latomus, 1970), 71; quoted from R. Bauckham, 'The Economic Critique of Rome in Revelation 18', in L. Alexander, Images of Empire (JSOTSS 122; Sheffield: JSOT Press, 1991), 47-90, esp. pp. 62-63. The essay is reprinted as chapter 10 in his The Climax of Prophecy: Studies on the Book of Revelation (Edinburgh: T. \& T. Clark, 1992).

48 See Bauckham, 'Economic Critique', 63-64, with further references.

49 Tyre was prosperous under Muslim rule from 638 to 1124 . It was part of the Latin kingdom of Jerusalem in the twelfth and thirteenth centuries but fell to the Mamelukes and was destroyed in 1291 from which it never recovered its former importance. The UNESCO declared it a world heritage site in 1980 .

50 1:6 mentions only Gaza, but v. 8 adds Ashdod, Ashkelon and Ekron. Gath is conspicuous by its absence, but as S.M. Paul points out, 'No oracle against Philistia anywhere in prophetic literature records all five names of the Philistine cities' (Amos [Minneapolis: Fortress Press, 1991], 16). The entire Philistine realm is in view here. Gath may have been less influential at the 
Mediterranean coast are guilty of complicity in the same crimeslave trade', 51 treating people as commodities. ${ }^{52}$ Whether the Edomites employed the slaves themselves in their extensive copper industry or merely functioned as middlemen is unknown, ${ }^{53}$ but the former is more likely as we would expect a similar accusation to be made against Edom in the latter case. The identity of the victim is not disclosed in this oracle, probably 'to place the emphasis upon the deplorable act itself rather than upon the specific party affected'. 54 The formulaic language used emphasises Yahweh's consistency in dealing with the nations. In the case of the Philistines and Tyre a similar crime leads to a similar punishment. ${ }^{55}$

That Sidon receives no separate attention in Amos ties in with the view that it was not an independent kingdom at the time, but incorporated into the kingdom of Tyre. ${ }^{56}$ In view of the commercial importance of Tyre as a trading port, it is not surprising to learn that traffic in human beings played a role in its transactions. It may be more astonishing that the trading partner should be Edom, since it is some land distance from Tyre and we have no other reference to trade relations between the two. ${ }^{57}$ Jeremias suggests that 'Edom' may be "meant typologically, similar to "Assyria" in many late Old Testament texts' and that the covenant reference is to the treaty

time; Gaza was possibly the most prominent either generally or with regard to the slave trade.

51 Paul, Amos, 57.

$52 \mathrm{Cf}$. the references to Tyre's slave trade in Ezk. 27:13 and Joel 4:6 (ET 3:6).

53 The latter was advocated e.g. by U. Kellermann, 'Israel and Edom' (Ph.D. diss., Münster, 1975), 39-40, referred to in J. Jeremias, The Book of Amos (Louisville, KY: W/JKP, 1998), 30, and Müller, 'Phönizien', 194, who suggests that the Sabean slave trade was via Edom (cf. Joel 4:8 [ET 3:8]).

54 Paul, Amos, 61.

55 This is really true for the whole of 1:3-2:3; see R. Meynet, Rhetorical Analysis: An Introduction to Biblical Rhetoric (JSOTSS 256; Sheffield: SAP, 1998), 293-96.

56 See e.g. Katzenstein, History, 132.

57 Although Katzenstein suggests that one reason for Tyre's presence in Jerusalem at the congress in 594/3 BC (cf. Je. 27:3) might have been its desire to improve trading contacts with the Negeb, which had apparently been handed over to Edom (cf. Je. 13:19; History, 316). This would be another instance of long-distance land trade. Many scholars favour an emendation of ארם אדום. This would fit particularly well a time just after Jeroboam II when Aram seems to have taken over territories from Israel, conceivably with the help of Phoenicia; see B. Oded, 'The Historical Background of the Syro-Ephraimite War Reconsidered', $C B Q 34$ (1972), 153-65, for an account of the power struggles at the time. But there is no textual support for such an emendation and it is therefore rejected by, e.g., Paul, Amos, 59-60; Jeremias, Amos, 27, 30. 
between (David and) Solomon and Hiram. ${ }^{58}$ This may well have been how the text was read later, but seems less likely to be the original understanding if the oracle is an early and integral part of the book..$^{59}$ As we have seen, neither the Assyrian campaign in $720 \mathrm{BC}$ nor that in $701 \mathrm{BC}$ saw Tyre conquered and burnt. Yet the fact that Tyre was not actually burnt in the eight century should not be used to argue that the prophecy did not prove true. It is important to observe that Tyre's punishment is described in terms of standard practice in ancient Near Eastern warfare. It simply repeats the threat against Gaza (v. 7) and reflects none of the characteristics of Tyre as an island-city. We are not given any detailed glimpses of future events in Tyre. The future that awaits Tyre is the necessary consequence of the present situation which calls for God's judgement. And, as Amos said even before the passages from Isaiah discussed above, 'Surely, the Lord Yahweh does nothing, without revealing his secret to his servants the prophets' (3:7).

The oracle against Tyre in Isaiah 23 is the last in a series of oracles against specific nations. ${ }^{60} \mathrm{~A}$ summons to lament pictures drastically the consequences of the fall of Tyre and Sidon, the latter maybe standing as a general reference to 'Phoenicia'. Yet Tyre is promised that after seventy years it will again resume its tradeexcept that from then on its profits and merchandise will be dedicated to Yahweh and will supply his people (vv. 17-18).

Diplomatic representatives from Tyre are mentioned in Jeremiah 27:1-3 as part of an international congress that met in Jerusalem and in which Ammon, Edom, Moab and Sidon were involved as well. It is noteworthy that Sidon has an independent representative. This meeting in the fourth year of Zedekiah's reign was either the meeting of an anti-Babylonian coalition or maybe more likely the attempt to form one. Jeremiah, however, warns these nations against challenging the divinely ordained domination of Babylon and announces that God will punish any nation that refuses to serve Nebuchadrezzar (27:4-11). We are not informed about the outcome of this congress. It is noteworthy that no representatives from the

\footnotetext{
58 Jeremias, Amos, 30.

59 As is argued by W. Rudolph, Joel, Amos, Obadja, Jona (KAT 13/2; Gütersloh: Mohn, 1971), 119-22; Hayes, Amos, 52-55, 86-89; Paul, Amos, 17-19.

60 J.D.W. Watts, Isaiah 1-33 (WBC 24; Waco, TX: Word, 1985), makes a good case for seeing closer links between the oracles against the nations in chs. 13-23 and the 'Isaiah apocalypse' in chs. 24-27. But chs. 24-27 deal with Syria-Palestine, Mesopotamia and Egypt as a whole rather than with particular nations.
} 
Philistine cities or from Egypt were present. My own guess (and it cannot be much more than an informed guess) is that Egypt under Pharaoh Psammetichus II (594-588 BC) was not interested in challenging Babylon and Zedekiah made therefore an attempt to form an alliance of some of the smaller nations. With the accession of Hophra, Egypt renewed its interest in Palestine. ${ }^{61}$ Possibly because the international congress early in his reign failed, Zedekiah was willing to ally himself with Egypt now and rebelled against Babylon. But the Phoenician kings were not willing to ally themselves with Egypt and Hophra engaged in battle with them. ${ }^{62}$ Tyre apparently tried to defend its relative independence against both empires (or maybe sought to be on good trading terms with both), but it is not entirely clear whether Nebuchadrezzar fought Tyre on account of its rebellious independence or because Hophra succeeded in forcing the Phoenician cities to support him.63 It is clear however that Jeremiah's basis for his prediction of doom for all nations that will not submit to Nebuchadrezzar is his knowledge of Yahweh's plan: to have all the nations drink from his cup of wrath (25:17-26). Thus as part of his ministry the prophet had to proclaim judgement on the nations (chs. 46-51; cf. 1:5b).

Surprisingly, Tyre is not addressed by Jeremiah in a separate oracle. It is only mentioned in $47: 4$ in an oracle against the Philistines. The MT suggests that the Philistines were the "surviving helper' of the Phoenician cities, although the LXX speaks about 'Tyre and Sidon and all the rest of her allies', leaving the relationship between the Phoenicians and the Philistines unclear. On the one hand, it is difficult to picture the Philistines as the 'surviving helper' of the Phoenicians. On the other hand, some sort of relationship between the Philistines and the Phoenicians is implied by the reference to Tyre and Sidon in an oracle against the Philistines. Maybe we should accept Holladay's proposal to vocalise the verb as the niphal infinitive in which case the $\zeta$ introduces the agent and the meaning is that the Philistines will be cut off from every ally, including Tyre and Sidon. ${ }^{64}$ It is interesting to compare this with Amos 1:6-10 where, as we have seen above, the Philistines and the

61 See Katzenstein, History, 316-18.

62 See Katzenstein, History, 318.

63 See Katzenstein, History, 318-20. J.T. Strong, 'Tyre's Isolationist Policies in the Early Sixth Century BCE: Evidence from the Prophets', VT 47 (1997), 207-219, relates Amos 1:9-10 to the congress in Jerusalem and suggests that it concluded with a treaty whose obligations were not fulfilled by Edom and Tyre.

64 W.L. Holladay, Jeremiah 2 (Minneapolis: Fortress Press, 1989), 334, 338. 
Phoenicians are charged with the same crime. There might well have been a commercial as well as a military alliance between the Phoenicians and the Philistines.65 In any case, the only thing announced in this oracle with regard to Tyre is the break-up of an alliance with the Philistine cities as a result of Yahweh's destruction of the Philistines. 66

Ezekiel pays much more attention to Tyre, devoting three chapters to the downfall of the island-city and its king in an ABAB pattern:67

A Announcement of judgement upon Tyre (26:1-21)

B Lament over the fall of Tyre (27:1-36)

A Announcement of judgement upon the king of Tyre (28:1-10)

B Lament over the fall of the king of Tyre (28:11-19)

In both cases a non-figurative oracle is followed by a figurative one.68 A brief oracle against Sidon (28:21-23) is attached to the collection of oracles against Tyre. Sidon is clearly regarded as the less important of the two cities. A late oracle against Egypt in 29:1721 dated to $571 \mathrm{BC}$ is also relevant because it looks back at Nebuchadrezzar's attempts to raze Tyre. The Ezekiel material will be discussed below.

Joel 4:4-8 (ET 3:4-8) seems to refer to the same context as Ezekiel 25-26, namely the benefit from the fall of Jerusalem sought by neighbouring countries. ${ }^{69}$ 'Tyre and Sidon, and the regions of Philistia' are accused of having enriched themselves with Yahweh's gold and silver and having 'sold the people of Judah and Jerusalem to the Greeks' (vv. 5-6; cf. vv. 2-3). Yahweh announces that he will

65 See W. McKane, A Critical and Exegetical Commentary on Jeremiah, vol. II: Commentary on Jeremiah XXVI-LII (Edinburgh: T. \& T. Clark, 1996), 1148-49, for a fuller discussion.

66 Note that again a typological (eschatological) reading of the chapter seems possible, but only as a secondary reading; see McKane, Jeremiah, 2:1145-46.

67 See Block, Ezekiel 25-48, 28. Ch. 26 follows a collection of briefer oracles against the Ammonites, Moab, Edom and the Philistines in ch. 25.

68 See Greenberg, Ezekiel 21-37, 576.

69 The evidence for dating the book of Joel is inconclusive and the exile referred to could be that after $701 \mathrm{BC}$, for which see S. Stohlmann, 'The Judean Exile after 701', in W.W. Hallo et al. (eds.), Scripture in Context II: More Essays on the Comparative Method (Winona Lake, MN: Eisenbrauns, 1983), 147-75. But on balance, a post-exilic date may be preferable; see e.g. J.A. Thompson, 'The Date of Joel', in H. Bream et al. (eds.), A Light unto My Path: OT Studies in Honor of J.M. Myers (Philadelphia: Temple University Press, 1974), 453-64; L.C. Allen, Joel, Obadiah, Jonah and Micah (Grand Rapids, MI: Eerdmans, 1976), 19-25; D.A. Hubbard, Joel \& Amos: An Introduction \& Commentary (TOTC 22B; Leicester: IVP, 1989), 23-27. 
bring back his people and proclaims a punishment that fits the crime: the slave-traders will themselves be sold to the people of Judah, who will sell them to a distant people, the Sabeans in Arabia. ${ }^{70}$ There are parallels with Amos 1 in linking the Philistines and the Phoenicians to slave trade and in the stereotypical description of the judgement, although here in poetic rather than formulaic language: 'the Hebrews, who had no love for the sea, were sold to sea-peoples; the people of Phoenicia and Philistia, seasoned sea-goers, will be sold to the Sabeans, desert dwellers.' 71 Again it is probable that this was meant not so much as a precise description of the future than as a pledge that Yahweh will redress the situation. It is likely however that the audience expected a literal enslavement of Phoenicians and Philistines, even if the reference to the Sabeans was understood as a poetic description of that slavery. ${ }^{72}$ The people of Sidon were indeed sold into slavery in $345 \mathrm{BC}$ by Artaxerxes III (359-338 BC), while the citizens of Tyre and Gaza were enslaved by Alexander in 332 BC. ${ }^{73}$

The last reference to Tyre in prophetic literature left to be discussed here is Zechariah 9:2b-4. ${ }^{74}$ Again the word against Tyre and Sidon is next to a word against Philistine cities, but in contrast to

70 For the people of Sheba as traders, cf. Is. 60:6; Je. 6:20; Ezk. 27:22. Note that the direction of the slave traffic is now precisely opposite, from the Greeks in the north-west to the Sabeans in the south-east (see Allen, Joel, 11314).

71 Hubbard, Joel \& Amos, 77.

72 But note M. Hengel's observation: 'The slave trade with southern Arabia is confirmed by the hierodule inscription of $\mathrm{Ma}^{\text {' }} \mathrm{i} n$, which mentions 28 slave girls from "Gaza" and only 8 from Egypt' (Judaism and Hellenism: Studies in Their Encounter in Palestine during the Early Hellenistic Period, Volume One [London: SCM Press, 1974], 42).

73 At the time of Judas Maccabeus the situation seems to have been reversed again: captured Jews being sold into slavery under the instigation of Ptolemy, the governor of Coelesyria and Phoenicia (2 Mac. 8:8-11).

74 There is possibly a reference to Tyre in Ho. 9:13, but most commentators abandon the MT in favour of the LXX reading (e.g. H.W. Wolff, Hosea: $A$ C'ommentary on the Book of the Prophet Hosea [Philadelphia: Fortress Press, 1974], 160-61) or interpret לצור differently, e.g. 'by the rival' (F.I. Andersen and D.N. Freedman, Hosea: A New Translation with Introduction and Commentary [AB 24; New York: Doubleday, 1980], 544); 'a palm-tree' (J. Jeremias, Der Prophet Hosea [ATD 24/1; Göttingen: Vandenhoeck \& Ruprecht, 1983], 119; cf. A.A. Macintosh, Hosea [Edinburgh: T. \& T. Clark, 1997], 370-73). See J.K. Kuan, 'Hos 9:13 and Josephus, Antiquities ix, 27187', PEQ 123 (1991), 103-108; T. McComiskey, 'Hosea' in T. McComiskey, The Minor Prophets: An Exegetical \& Expository Commentary, vol. I (Grand Rapids, MI: Baker Book House, 1992), 150-51; and F. Landy, Hosea (Sheffield: SAP, 1995), 119-20, for recent attempts to read 'Tyre'. At best, Ho. 9:13 tells us that there was a common expectation that Tyre would be judged (so McComiskey) and does not contribute more to our discussion. 
Jeremiah the destruction of the Phoenician cities seems to be a foreboding of the destruction of Ashkelon, Gaza, Ekron and Ashdod (again Gath is left unmentioned).

Tyre has built itself a rampart and heaped up silver like dust and gold like the mud of the streets. But now, the Lord will strip it of its possessions and hurl its army/wealth into the sea, and it shall be devoured by fire (vv. $3-4) .75$

No specific charge is levelled against Tyre. Yet the introduction to these verses says that 'Tyre and Sidon, though they are wise' belong to Yahweh just like all the other nations. The implication seems to be that everything was subordinated to the creation of wealth. Tyre's wisdom is acknowledged in Ezekiel as well, but it seems to have been a wisdom solely employed for the purpose of enriching oneself (cf. Ezk. 28:3-5). The punishment announced reads like a free adaptation from both Amos ('devoured by 'fire') and Ezekiel ('hurled into the sea'). It is not clear whether a specific historical reference is intended or whether the oracle is typologicaleschatological from its inception. The latter would explain that Tyre, which was more important than Sidon throughout Israelite history, is mentioned prior to Sidon which was (again) the more prominent of the two from the Persian period onwards. Thus C.L. Meyers and E.M. Meyers argue that in view of the overall thrust of the chapter, 'Rather than reflecting a specific event, Zech 9:1-8 deals with a catalogue of Israel's archetypal enemies ${ }^{176}$ with the aim of giving a promise of the restoration and security of the land of Israel (v. 8). H. Graf Reventlow suggests that Second Zechariah immediately confronts interpreters with the question whether to search for a specific historical background or to look for an alternative way of reading the text and notes that the latter approach is gaining in popularity. ${ }^{77}$ The oracle seems to combine the different concerns of Isaiah and Ezekiel and we will therefore briefly return to Zechariah 9 when we compare the Tyre prophecies in Isaiah and Ezekiel.

חיל 75 can be translated 'army' or 'wealth'; 'wealth' fits the context well, but 'army' preserves the allusion to Ex. 15:4.

76 C.L. \& E.M. Meyers, Zechariah 9-14: A New Translation with Introduction and Commentary (AB 25C; New York: Doubleday, 1993), 99; cf. K. Larkin, The Eschatology of Second Zechariah: A Study of the Formation of a Mantological Wisdom Anthology (CBET 6; Kampen: Kok Pharos, 1994), 5467.

77 H. Graf Reventlow, Die Propheten Haggai, Sacharja und Malachi (ATD 25/2; Göttingen: Vandenhoeck \& Ruprecht, 1993), 90. 


\section{The proclamation of Tyre's future in Isaiah}

\section{Yahweh's plan according to the book of Isaiah}

The more extensive prophecies concerning Tyre in Isaiah and Ezekiel invite us to place them more explicitly in the context of the rhetorical thrust or 'message' of the respective prophetic books. Of course, to state the 'message' of a book like Isaiah is not an easy task. Yet it would seem that significant progress has been made in recent years. Many scholars would agree that two essential aspects of the 'message' of the book of Isaiah are Yahweh's plan for a new world order and the transformation of Zion. ${ }^{78}$ Yahweh's plan has a shortterm and a long-term aspect. For the time being, Yahweh will exercise his lordship via Assyrian, Babylonian and Persian hegemony; in the long run Yahweh's world dominion will again be established in Zion. ${ }^{79} \mathrm{~A}$ number of scholars emphasise that 'Isaiah is not thinking in terms of a plan that is hard and fast in all its details. ${ }^{80}$ What the book of Isaiah does is to announce Yahweh's strategy for the present situation, to confront God's people with the consequences of disloyalty to Yahweh and challenge them to faith, as well as to proclaim Yahweh's long-term goal. The way from the present situation to the (eschatological?) goal is only sketched out.

It is proposed to look at one or two passages earlier in the book before we discuss ch. 23. Isaiah 2 presents for the first time the longterm perspective ('In days to come, the mountain of Yahweh's house shall be established as the highest of the mountains and shall be raised above the hills; all the nations shall stream to it', v. 2) and

78 The motif of Yahweh's plan was highlighted by J. Fichtner, G. von Rad and $\mathrm{H}$. Wildberger; more recently see e.g. Watts, Isaiah 1-33, Iv-lvi; J. Jensen, 'Yahweh's Plan in Isaiah and in the Rest of the Old Testament', $C B Q 48$ (1986), 443-55; M.A. Sweeney, Isaiah 1-4 and the Post-exilic Understanding of the Isaianic Tradition (BZAW 171; Berlin: de Gruyter, 1988), 96-99. For the transformation of Zion, see also B.G. Webb, 'Zion in Transformation', in D.J.A. Clines et al. (eds.), The Bible in Three Dimensions: Essays in Celebration of Forty Years of Biblical Studies in the University of Sheffield (JSOTSS 87; Sheffield: JSOT Press, 1990), 65-84.

79 For a different but complementary perspective see J.N. Oswalt, "The Kerygmatic Structure of the Book of Isaiah', in J. Coleson and V. Matthews (eds.), 'Go to the Land I Will Show You': Studies in Honor of Dwight W. Young (Winona Lake, IN: Eisenbrauns, 1996), 143-57.

80 Jensen, 'Yahweh's Plan', 446, summarising H. Wildberger, 'Jesajas Verständnis der Geschichte', in Congress Volume Bonn 1962 (SVT 9; Leiden: Brill, 1963), 83-117. Cf. B. Albrektson, History and the Gods: An Essay on the Idea of Historical Events as Divine Manifestations in the Ancient Near East and in Israel (Lund: Gleerup, 1967), 68-97. 
challenges Israel to live in the light of this vision provided by their covenant God, before it spells out the consequences on a wider scale:

The haughty eyes of humanity shall be bowed down, and the exaltation of people shall be brought low; and Yahweh alone will be exalted in that day. For Yahweh of Hosts has a day against all that is proud and exalted, against all that is lifted up - and it shall fall...against all the ships of Tarshish, and against all the beautiful vessels. The haughtiness of humanity shall be brought low, and the exaltation of everyone shall be bowed down; and Yahweh alone will be exalted in that day $(2: 11-12,16-17)$.

Before being given any specific prediction of the fall of cities and nations, we are offered this vision which will provide the framework for the prophecies to follow. The application is made first to the people of Judah and Jerusalem who are challenged not to put their trust in anyone or anything but Yahweh himself. ${ }^{81}$ For Israel, the humiliation of haughty people is not an event in the distant future only, but one that occurs in historical events that are very close:

Humanity is brought low, everyone is bowed down, and the eyes of the haughty are bowed down. But Yahweh of Hosts is exalted in justice, and the Holy God shows himself holy in righteousness (5:15-16).

It is in this context that the book of Isaiah mentions 'the plan of the Holy One' for the first time (5:19) and it is in this context that Isaiah sees 'the Lord sitting on a throne, high and lofty' (6:1) looking for someone who will prepare the people of God for judgement. Strikingly, the first reference to 'the plan of the Holy One' is in a quotation of Isaiah's opponents who do not reckon with God fulfilling his purpose. Yet, because Zion participates in humanity's attempt to exalt itself and thus to occupy the position that belongs to God, it will have to be brought low before it can become the place envisaged in ch. 2.82

The collection of oracles against the nations (chs. 13-23) opens with an oracle against Babylon and closes with an oracle against Tyre. Thus the great city in the east renowned for its military might (cf. 14:16-17) and the great city in the west renowned for its

81 In view of Ezekiel's emphasis on the beauty of Tyre, it is noteworthy that in Isaiah the beauty of the 'haughty daughters of Zion' is removed (3:18-4:1), before 'on that day' beauty will be with the remnant (4:2-6).

82 It may be that references to Israel/Jacob in chs. 1-12 are to the northern kingdom as Watts, Isaiah 1-33, and M.A. Sweeney, Isaiah 1-39 with an Introduction to Prophetic Literature (FOTL 16; Grand Rapids, MI: Eerdmans, 1986), argue. Yet for the purpose of the argument at hand it seems unnecessary to differentiate carefully between Israel and Judah. 
commercial enterprise (cf. 23:3, 8) bracket the collection, maybe inviting readers to see God at work in human affairs more generally as well as in the specific situations addressed in the oracles. The rationale for punishment remains the same: 'I will punish the world for its evil, and the wicked for their iniquity; I will put an end to the pride of the arrogant, and lay low the insolence of tyrants' (13:11; cf. $14: 8 \mathrm{~b})$. The 'day of Yahweh' is a day against all self-aggrandisement (cf. 14:12-15). ${ }^{83}$ The language of God's plan is taken up in the pronouncements against Assyria/Babylonia:

Yahweh of Hosts has sworn: As I have designed, so shall it be; and as I have planned, so shall it come to pass: to break the Assyrian in my land, and on my mountains I will trample him under foot. His yoke shall be removed from them, and his burden shall be removed from their shoulders. This is the plan that is planned concerning the whole earth; and this is the hand that is stretched out over all the nations. For Yahweh of Hosts has planned, and who can annul it? His hand is the one stretched out, and who can turn it back? $(14: 24-27)^{84}$

The judgement on Assyria/Babylon and the other nations is certain, not because the prophet had a vision of the future but because Yahweh has purposed it and no-one can thwart God's hand. This 'it

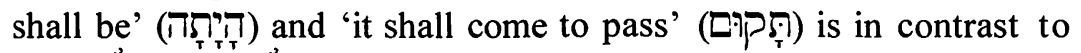
7 7:7 which is said about what Judah's enemies have planned $(\gamma \stackrel{\text {, }}{\top}, 7: 5) .85$

\section{The place of Tyre in Yahweh's plan}

The pronouncement concerning Tyre is placed after that concerning 'the valley of vision' (presumably the Kidron valley) and thus occupies a prominent place in the final form of the book. The references to Judah, Jerusalem and the house of David in ch. 22 bring the Judaean audience back to Yahweh's dealings with themselves before the prophecy against Tyre marks the conclusion to the oracles against specific nations. The (Tyre-built) 'ships of Tarshish' (2:16) and the tall trees of Lebanon (10:33-34) have been used as images of loftiness before in the book. It is therefore not surprising that Yahweh's plan includes the humiliation of Tyre and Sidon. The emphasis of the oracle is first of all on the impact the fall of Tyre has on merchants all over the Mediterranean. Tyre was 'the

83 See also 16:6 for Moab's pride. Ch. 10 had already announced that Assyria, God's first instrument for punishing his people ( $v v .4-5$ ), will be punished for its pride (vv. 12-19).

84 Note also the references to Yahweh's plan in 19:12, 17 in an oracle concerning Egypt.

85 See Wildberger, 'Jesajas Geschichtsverständnis', 88. 
merchant of the nations' (v. 11) and its fall leaves the whole region in shock:

Who has planned this against Tyre, the bestower of crowns, whose merchants are princes, whose traders are the honoured of the earth/land? Yahweh of Hosts has planned it-to defile the pride of all glory, to shame all the honoured of the earth/land (vv. 8-9).

Tyre, like Assyria and Babylon, illustrates the pride of humanity that must be judged by Yahweh. The chapter uses the rhetorical device of lamenting a disaster as if it had already happened to stress the certainty of its coming (cf. Am. 5:2; Ezk. 19; 27; 28:11-19; Zc. 11:2-3). Following Lindblom, Wildberger argues that v. 12 forbids reading the chapter as a prediction, but his argumentation is not convincing. ${ }^{86}$ While it is possible that only the epilogue is a prediction, the literary context should incline readers to take the poem as predictive as well. ${ }^{87}$ One might also expect more precision if the lament had indeed been written after the event. The historical events to which this chapter refers are, however, difficult to determine and are the subject of wide disagreement. During Isaiah's lifetime the pronouncement could refer to Shalmaneser's campaigns against Tyre between 725 and $723 \mathrm{BC}$, to the destruction of Sidon by Sargon II in $720 \mathrm{BC}$, or to the break-up of the kingdom of Tyre through Sennacherib in $701 \mathrm{BC}$. In all cases, Tyre itself was not destroyed.

The references to 'ships of Tarshish' in vv. 1, 10, 14 suggest that Tarshish was still closely related to Tyre (and Sidon); if not, the invitation in v. 6 to cross over to Tarshish certainly seems to imply as much, even though the call is of course not be taken literally. Wildberger claims that Tarshish was lost in the seventh century to the Phochaean Greeks. ${ }^{88}$ Indeed, it seems that Tyre had lost control over Tarshish by the seventh century, even though the Phochaeans

86 H. Wildberger, Isaiah 13-27: A Continental Commentary (Minneapolis, MN: Fortress Press, 1997), 413-14; cf. J. Lindblom, 'Der Ausspruch über Tyrus in Jes 23', ASTI 4 (1965), 56-73. As regards the reason for the composition of this poem, Wildberger writes: 'this author serves as a witness that these events have been determined beforehand by the decision of Yahweh and that Yahweh has his good reasons for causing this particular turn of events in Phoenicia's history' (414).

87 The wider definition of divine revelation' that 'responds to a question about a lack of clarity in the relation between divine intention and human reality' ('Oracle', $A B D$ 5:28) fits either interpretation. Watts points out that the meaning 'a threat of doom' fits all occurrences in Isaiah (Isaiah I-33, 190-91).

88 Wildberger, Isaiah 13-27, 416, assuming the most common identification of

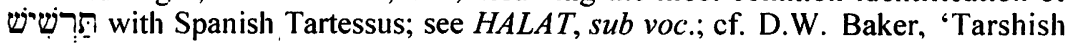
(Place)', $A B D$ 6:331-33. 
appear there only in the sixth century ${ }^{89}$ In any case, this makes a fourth century date for the oracle, as is often suggested, ${ }^{90}$ less likely. Similarly, the impression is given that Cyprus had not only commercial relations with Phoenicia but was actually a potential place of refuge for them. At the least, the oracle presupposes that the readers are still aware that (part of) Cyprus once belonged to the Phoenicians. As has been mentioned above, Cyprus came under Assyrian control in $709 \mathrm{BC}$. While the Phoenicians on the island retained their local king and relative independence, they had to renounce their allegiance to Tyre. ${ }^{91}$ The subsequent history of Cyprus is somewhat obscure but the inhabitants of the island may have been able to throw off the yoke of Assyria in the first years of Ashur-banipal. ${ }^{92}$ The island lost its independence however to Egypt during the reign of Amasis (570-526 BC), probably in about $560 \mathrm{BC}$. Some fifteen years later the Cypriots submitted to Cyrus, and Darius (521-485 BC) made the island part of the fifth satrapy. But the inhabitants of the island grew more and more antagonistic to Persian rule and friendly to the Greeks. ${ }^{93}$ The references to Cyprus in Isaiah 23 seem less relevant in that late period and suggest an earlier date in the Assyrian period when Cyprus was just about to loosen its close political contact with Tyre. ${ }^{94}$ Most commentators in fact link the oracle with one of Esarhaddon's campaigns, usually that in $671 \mathrm{BC}$ to which reference was made above. Yet a plausible alternative is Sennacherib's campaign in $701 \mathrm{BC}$ which allows for Isaianic authorship. ${ }^{95}$

89 Wildberger refers to Herodotus 1.163 and 4.152 . The second passage tells about the Samian Colaeus who in about $638 \mathrm{BC}$ shipwrecked in Tartessus where he apparently found 'a virgin port, unfrequented by the merchants' but a rich market for metals. The first passage narrates how the Phochaeans established trade relationships with Tarshish in the sixth century.

90 E.g. by Kaiser, Isaiah 13-39, 162-68, who by reading פִִּתיִים (Cyprus) instead

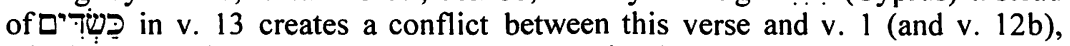
which allows him to conclude: 'Thus the tension between $v .1$ and the historical facts known to us may be ignored, particularly as we do not know to what extent sea traffic between the Phoenician cities and Cyprus was in fact restricted' (163).

91 Karageorghis, 'Cyprus', $C A H^{2}$ III, 3:60.

92 Karageorghis, 'Cyprus', $C A H^{2}$ III, 3:59.

93 Karageorghis, 'Cyprus', $C A H^{2}$ III, 3:65, 70.

94 Maier, 'Cyprus and Phoenicia', 319, concludes from the sarcophagus of a minister of Tyre found in Citium that formal relations between the two cities existed as late as the fourth century BC.

95 See the detailed discussion in Sweeney, Isaiah 1-39, 307-309; cf. J.A. Moyter, The Prophecy of Isaiah (Leicester: IVP, 1993), 192. A few older commentators preferred Shalmaneser's campaign; so $\mathrm{C}$. von Orelli, The 
V. 13 adds support to the view that the oracle is from the Assyrian period, even if the usual translation and interpretation of the verse, which suggests that an Assyrian period prophecy has been re-used during or after the Babylonian period, is rejected. 'This common understanding is reflected e.g. in the NRSV translation:

Look at the land of the Chaldeans! This is the people; it was not Assyria. They destined Tyre for wild animals. They erected their siege towers, they tore down her palaces, they made her a ruin.

Such an understanding of the, admittedly difficult, Hebrew text is however not reflected in any of the ancient versions. A more literal translation reads:

Look at the land of the Chaldeans! This is the people that was not [has become nothing]. Assyria destined it [the land] for wild animals. They erected siege towers against it [the people], ${ }^{96}$ they tore down its palaces, they made it a ruin.

Watts correctly points out that the destruction of Babylon is a major theme of this collection. It could therefore suitably be held up to Tyre as an example of Yahweh's plan to humble proud countries. ${ }^{97}$ Yet the verse does not mention the sack of Babylon explicitly and thus could refer to Sennacherib's earlier invasion in $703 \mathrm{BC}$, during which Assyria did considerable damage to the land of the Chaldeans, although Babylon itself was left intact.98 The verse

Prophecies of Isaiah (Clark's Foreign Theological Library, New Series 38; Edinburgh: T. \& T. Clark, 1889), 138; J. Skinner, The Book of the Prophet Isaiah: Chapters I-XXXIX (Cambridge: CUP, 1915), 185-86. But his campaign seems to have had comparatively little impact on Phoenicia.

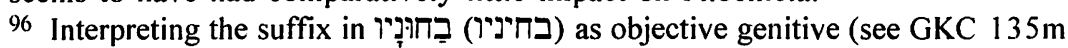
for other examples) referring back to עָ עָ back to she while the third line could refer either to the land or to the city

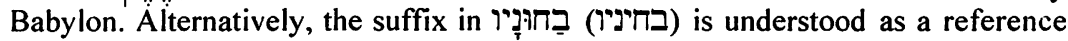
to Assyria, so probably in the Hebrew manuscript that reads the singular ('he erected'); see $B H S$. 1QIsa ${ }^{a}$ reads 'her siege towers', see Watts, Isaiah 1-33, 302.

97 Watts, Isaiah 1-33, 303, relating the verse to Sennacherib's razing of Babylon in December $689 \mathrm{BC}$. Delitzsch reverses the relationship and sees a reference to the fall of Nineveh in $606 \mathrm{BC}$, chiefly because he thinks the oracle must apply to the Babylonian siege of Tyre (Biblical Commentary on the Prophecies of Isaiah [Clark's Foreign Theological Library IV, 14; Edinburgh: T. \& T. Clark, 1869], 1:411-14).

98 So Katzenstein, History, 249-51; Sweeney, Isaiah 1-39, 308. Cf. S. Erlandsson, The Burden of Babylon: A Study of Isaiah 13:2-14:23 (ConBOT 4; Lund: CWK Gleerup, 1970), 97-102. If the destruction of Babylon itself is implied in v. 13, the verse originated after $689 \mathrm{BC}$ but before Babylon was rebuilt by Esarhaddon in $676 \mathrm{BC}$. Because they link the oracle with Shalmaneser's campaign, von Orelli and Skinner are inclined to change the 
probably suggests that Assyria will be the executor of Yahweh's punishment in the case of Tyre as much as in the case of Babylonia, although this is not definitely required.

The summons to lament ends in v. 14. As we have seen, a number of historical linkages can be made, but again we cannot be certain about any close connection with a particular historical event. This is partly because our source material is insufficient, but it is also to do with the fact that the pronouncement is not very specific apart from the apparent completeness of the fall of Tyre which stops the productivity of the sea. ${ }^{99}$ Yet Tyre has not been destroyed during the Assyrian, Babylonian or Persian periods. When Tyre was finally conquered by Alexander, the specific references in the chapter to the 'ships of Tarshish' and Cyprus, but also the designation of Tyre as 'the bestower of crowns', are no longer as rhetorically effective as they would have been in the Assyrian period. 100

The oracle concludes with a promise of Tyre's restoration (vv. 1518). Many scholars suggest that vv. 17-18 is a late gloss, ${ }^{101}$ possibly meant to lessen the hostility of the oracle. ${ }^{102}$ Kaiser claims that Tyre was given back full autonomy by Ptolemy Philadelphus in 274 BC, the year that Tyre abandoned its monarchical structure and adopted a government by executive magistrates similar to Carthage, about 60 years after the destruction through Alexander. Supposing that the redactor worked after this date, he suggests that the verse indicates how intensive eschatological expectations were in the third century. ${ }^{103}$ Yet it is unlikely that greater autonomy was granted to

Hebrew text of v. 13. Alternatively, they would have to regard the verse as a later gloss.

99 See v. 4. According to v. 10 Tyre will have to resort to agriculture. Wildberger correctly speaks of 'the complete destruction of the maritime commercial activities of Tyre' (Isaiah 13-39, 433). Sweeney overstates his case in claiming that the passage 'speaks only generally of humiliation, downfall, and the lack of protection' (Isaiah 1-39, 307).

${ }^{100}$ See Wildberger, Isaiah 13-39, 417, 429.

${ }^{101}$ E.g. W. Eichrodt, Der Herr der Geschichte: Jesaja 13-23/28-39 (BAT 17, 2; Stuttgart: Calwer Verlag, 1967), 112-14; O. Kaiser, Isaiah 13-29 (2nd ed.; London: SCM Press, 1980), 169-72.

102 Although P. Höffken, Das Buch Jesaja: Kapitel 1-39 (NSKAT 18/1; Stuttgart: KBW, 1993), 175, thinks even vv. 17-18 are cynical (most agree that this is true for vv. 15-16).

${ }^{103}$ Kaiser, Isaiah 13-29, 171, with reference to E. Schürer, Geschichte des jüdischen Volkes im Zeitalter Jesu Christi § 23, vol. Il (4th ed.; Leipzig, 1907), 98, and F.-M. Abel, Histoire de la palestine: Depuis la conquête d'Alexandre jusqu 'à l'invasion Arabe, vol. I: De la conquête d'Alexandre jusqu'à la guerre juive (Paris: Gabalda, 1952), 52, but neither of them provides hard evidence for the claim made. 
the Phoenician cities at that time. ${ }^{104}$ Sweeney relates the seventy years to the time from Sennacherib's campaign in $701 \mathrm{BC}$ to the recovery of Tyre with the decline of the Assyrian empire in around $630 \mathrm{BC}$ and dates the verses to the early reign of Josiah during which, he argues, a renewal of trade relations between Tyre and Judah was expected.105 Tyre was of course not 'forgotten' during that period and neither did it have to resort to agriculture. Esarhaddon's campaigns are proof that Tyre was still a troublesome city for the Assyrians. The promise thus seems to exceed the fulfilment, even when the oracle is not pressed for absolutely literal fulfilment.

The seventy years may well be symbolic, given that the book of Isaiah refers to a more specific period of time on another occasion (7:8) and that seventy years, roughly a normal human life span (cf. Ps. 90:10), are apparently not unique to the Bible as an extended period of destruction for a city or region. ${ }^{106}$ It is a way of saying that a new beginning could be made only after everyone alive at the time of the offence had died.107 The reference to the 'lifetime of a king' in v. 15 is more unusual and has yet to be explained satisfactorily. It is possibly meant to emphasise that along with its commercial rule Tyre's political independence will be gone for seventy years, after which Tyre's influence would again be felt. The character of the city would not change but its profits will be dedicated to Yahweh and his people. This motif of the wealth of the nations flowing to Zion had already been used in 18:7 (cf. 19:21) and becomes prominent later in

\footnotetext{
${ }^{104}$ For more details, see e.g. Jidejian, Tyre, 80-82; M. Hengel, Jews, Greeks and Barbarians: Aspects of the Hellenization of Judaism in the pre-Christian Period (London: SCM Press, 1980), 21-32; P. Green, Alexander to Actium: The Hellenistic Age (Berkeley: University of California Press, 1990), 131, 145-50; cf. E.R. Bevan, The Hour of Seleucus (London: Routledge \& Kegan Paul, 1966), 1:235. Ironically, Tyre's fortunes were on their way down during that period due to competition from Alexandria (see above). According to Moscati, Tyre and Sidon regained their autonomy as city-states in 120 and $111 \mathrm{BC}$ (World, pp. 26-27, cf. n. 18 on p. 247).

105 Sweeney, Isaiah 1-39, 309-310. Cf. Motyer, Isaiah, 192. Motyer relates the statement about the dedication of Tyre's commercial profits to Yahweh to a more distant time.

106 However, we do not know how common it was to designate seventy years as the time of punishment. I am aware of only one Assyrian example, an inscription of Esarhaddon (BM 78223) which is available in different versions; see R. Borger, Die Inschriften Asarhaddons Königs von Assyrien (Archiv für Orientforschung, Beiheft 9; Osnabrück: Biblio-Verlag, 1967), par. 11 (for an English translation see Luckenbill, Ancient Records, vol. II, par. 650; Albrektson, History, 91).

${ }^{107}$ Cf. Wildberger, Isaiah 13-39, 434-35; see p. 403 for further references.
} 
the book (see $45: 14 ; 60: 5-17 ; 61: 5-6$ ), where the 'ships of Tarshish' are said to bring back the exiles along with silver and gold (60:9) and 'the glory of Lebanon' beautifies the temple (60:13). The restoration of Tyre stands in contrast to the permanent destruction announced for Babylon (14:4-23; cf. 21:1-10) and Edom (34:5-17). Yet a 'conversion' of the Tyrians is not necessarily implied (contrast 19:21-22). The emphasis is on the movement of wealth towards Yahweh and his people. There seems to be an awareness that commerce will have to continue even though in the end it will be for the benefit of God's people. 108

It is noteworthy that, unlike the nations in previous oracles, Tyre is focused upon in Isaiah 23 not in isolation but as the centre of a network of economics and commerce. What happened in Tyre affected the rest of the land/world. The oracle thus provides a good link to chs. 24-27, which give a more general description of God's judgement of the nations. 109

It is concluded that the description of Tyre's fall and restoration in the book of Isaiah is again not detailed enough to allow a precise identification. This might well have been seen as an advantage by later readers who could see a multiple fulfilment of the oracle in the campaigns led against Tyre by Sennacherib, Esarhaddon, Nebuchadrezzar and Alexander. Whenever Tyre would rise again as a commercial power, readers could be assured by this oracle that Tyre will not be able to stand in its pride and that ultimately its wealth will benefit the people of God. We have evidence in the LXX and the Targum for the claim that later readers saw in this chapter potential for further fulfilment in their own time. The LXX of Isaiah 23 applies the oracle to Carthage, most likely because of Carthage's connection with Tyre. 110 The Targum implies that the Romans will be responsible for Tyre's downfall. It uses 'Kittim' as a cipher for the Romans and reads v. 12 as 'go into exile to Kittim'. 111 It is impossible

${ }^{108}$ See the interesting discussion by G.A. Smith, The Book of Isaiah, vol. I: Isaiah I.-XXXIX. (London: Hodder and Stoughton, 1889), 288-300.

109 Watts contends that 'Leviathan' in ch. 27 stands for Tyre (Isaiah 1-33, 298-99, 348-49). The argument is attractive but we do not have the space to discuss it here.

${ }^{110}$ See the splendid study by A. van der Kooij, The Oracle of Tyre: The Septuagint of Isaiah 23 as Version and Vision (SVT 71; Leiden: Brill, 1998).

11 See B.D. Chilton, The Isaiah Targum: Introduction, Translation, Apparatus and Notes (The Aramaic Bible 11; Edinburgh: T. \& T. Clark, 1987), 45-46. The cryptic titles of earlier oracles in this collection might even invite readers to see in 'Tyre' a cipher and apply the oracle to cities unrelated to Tyre but I have no evidence that this happened prior to the Middle Ages. 
for us to decide whether these ancient translators looked for another fulfilment of God's purpose in their own times or thought the prophet was really referring to their period of history. ${ }^{112}$ The former is certainly the case in the book of Revelation, where motifs related to Tyre are merged with motifs related to Babylon into a description of a 'Babylon' that stands for Rome which John saw 'as the successor to Tyre in its economic empire and the successor to Babylon in its political oppression'.113 Revelation 17:1-19:10 is informed by both Ezekiel 26-27 and Isaiah 23.114

\section{The proclamation of Tyre's future in Ezekiel}

The paper presents first an overview of Ezekiel's oracles against Tyre, then a discussion of the problem of unfulfilled prophecy drawing on Ezekiel 26:1-14 and 29:17-21, and finally a comparison between Isaiah's pronouncement and those in Ezekiel.

\section{An overview of oracles against Tyre in Ezekiel}

Ezekiel 25-32 comment on the reaction of neighbouring countries to the fall of Jerusalem and on Nebuchadrezzar's campaign in the west. The oracles show that Ezekiel, like Jeremiah, was convinced that Nebuchadrezzar was Yahweh's chosen instrument of judgement (cf. Je. 27). Thus, more clearly than any of the oracles discussed so far, the oracle against Tyre in Ezekiel addresses a specific historical

112 Both seem to be possible in the milieu of the time; see van der Kooij, Oracle, 88-109, who classifies the LXX of Isaiah 23 as an updated prophecy. J. Barton, Oracles of God: Perceptions of Ancient Prophecy in Israel after the Exile (London: Darton, Longman and Todd, 1986), 179-234, suggests the latter was prevalent at the time, although he acknowledges that the paradigmatic quality of biblical prophecy was fundamental for these later readers.

113 R. Bauckham, The Theology of the Book of Revelation (Cambridge: CUP, 1993), 153.

114 Apart from commentaries on Revelation, see esp. Bauckham, 'Economic Critique'. For the influence of Isaiah 23, see J. Fekkes, Isaiah and Prophetic Traditions in the Book of Revelation: Visionary Antecedents and Their Development (JSNTSS 93; Sheffield: JSOT Press, 1994), 211-12, 219-23, and of Ezekiel, J.-P. Ruiz, Ezekiel in the Apocalypse: The Transformation of Prophetic Language in Revelation 16,17-19,10 (European University Studies XXIII, 376; Frankfurt: Lang, 1989). Fekkes notes that the combination of two or more OT texts by analogy 'is one of John's favourite techniques' (227). The use of Babylon oracles against Rome is also found in the Sibylline Oracles (e.g. Sib. Or. 5.168-78; cf. Bauckham, 'Economic Critique', 89-90) and in Qumran (1QpHab; cf. 4QpIsa $\left.{ }^{\mathrm{a}}\right)$. 
situation. But the oracles against Tyre and Egypt in addition serve to clarify the nature of rebelliousness against Yahweh and expose its futility. Significantly, the oracles against Tyre parallel the island-city with Jerusalem using imagery more commonly related in the Old Testament to Zion. ${ }^{115}$ Thus in spite of the fact that a specific situation is addressed, the oracles have a paradigmatic character.

The first prophecy (26:2-6) links the pronouncements against Tyre with the preceding oracles in ch. 25 in establishing Tyre's glee over Jerusalem's fall as the reason for its punishment. ${ }^{16}$ The second prophecy (26:7-14) details the anticipated result of Nebuchadrezzar's campaign against Tyre, the third prophecy (26:15-18) describes the grief of the nations over Tyre's fall, and the fourth (26:19-21) underlines that the destruction of Tyre will mark its complete end. Set apart from the first series of prophecies by another prophetic word formula, the instruction to the prophet to raise a lament introduces the mytho-poetic dirge over the great ship Tyre in ch. 27.117 The chapter reveals an amazing knowledge of the various trade activities of Tyre. ${ }^{118}$ Tyre's anticipated disaster is no longer

${ }^{115}$ See my 'The Use of the Zion Tradition in the Book of Ezekiel', in R.S. Hess and G.J. Wenham (eds.), Zion, City of Our God (Grand Rapids, MI: Eerdmans, 1999), 77-103, esp. pp. 98-99; and The Rhetorical Function of the Book of Ezekiel (SVT 76; Leiden: Brill, 1999), 93-97.

116 Remarkably, this is the only prophecy against Tyre where the announcement of punishment is prefixed with the statement of a reason. One can thus differentiate between the oracles in ch. 25 which carry specific indictments and those in chs. 26-32 which by and large do not carry indictments, but use mythological motifs to condemn hybris; cf. J.B. Geyer, 'Mythology and Culture in the Oracles against the Nations', VT 36 (1986), 129-45.

${ }^{117}$ For a fuller discussion of the chapter see e.g. E.M. Good, 'Ezekiel's Ship: Some Extended Metaphors in the Old Testament', Semitica 1 (1970), 79-103; J.A. Durlesser, 'The Sinking of the Ship of Tyre (Ezk. 27): A Study of Rhetoric in Hebrew Allegory', Proceedings, Eastern Great Lakes and Midwest Biblical Societies 7 (1987), 79-93; J.B. Geyer, 'Ezekiel 27 and the Cosmic Ship', in P.R. Davies and D.J.A. Clines (eds.), Among the Prophets: Language, Image and Structure in the Prophetic Writings (JSOTSS 144; Sheffield: JSOT Press, 1993), 105-126. See also E. Strömberg Krantz, Des Schiffes Weg mitten im Meer: Beiträge zur Erforschung der nautischen Terminologie des Alten Testaments (ConBOT 19; Lund: Gleerup, 1982); H.J. van Dijk, Ezekiel's Prophecy on Tyre: A New Approach (Biblica et Orientalia 20; Rome: PBI, 1968), 48-91; C.A. Newsom, 'A Maker of Metaphors: Ezekiel's Oracles against Tyre', Interpretation 38 (1984), 151-64.

${ }^{118}$ See M. Liverani, 'The Trade Network of Tyre according to Ezek. 27', in M. Cogan and I. Eph'al (eds.), Ah. Assyria.... Studies in Assyrian History and Ancient Near Eastern Historiography Presented to Hayim Tadmor (Scripta Hierosolymitana 33; Jerusalem: Magnes Press, 1991), 65-79, and I.M. Diakonoff, 'The Naval Power and Trade of Tyre', IEJ 42 (1992), 168-93. 
linked to her joy over the fall of Jerusalem. Rather, Tyre's fall is a parallel to the fall of Jerusalem, being a fall from a privileged position. As Jerusalem 'in the centre of the nations' (5:5) became the focus of Yahweh's judgement, having become the centre of rebellion against Yahweh (5:6ff.), so Tyre, the ocean-going ship 'in the heart of the seas' (vv. 4, 25 = in the centre of the seas; cf. 28:2), will sink 'into the heart of the seas' (in vv. 26, $27=$ in the depth of the seas; cf. 28:8 and slightly differently phrased 27:32,34).119

As pointed out above, the same pattern of a prophecy (28:1-10) followed by a funeral lament (28:11-19) is employed in ch. 28. The story of Tyre's fall is now repeated with its ruler as the explicit subject. He is first depicted as someone claiming divinity then as the primeval human. ${ }^{120}$ The use of a lament conveys again the message that the subject is doomed. As in the previous chapter, the emphasis is on the reversal of fortunes from glory to disaster. Motifs which recall the Zion tradition create a link with the fall of Jerusalem. It is made even clearer in these passages that Tyre owed her prosperity to God (as did Jerusalem) and that it is Tyre's arrogance which leads to her destruction. It is not clear whether these passages also attempt to refute the ideology of divine kingship. It is more likely that the ruler stands as a symbolic figure for the city-state. ${ }^{121} \mathrm{~A}$ short

${ }^{119}$ Geyer, 'Ezekiel 27', 119ff., claims that no fewer than 30 substances mentioned in the trade list are elsewhere in the Hebrew Bible connected with the temple (or ark or tabernacle). This might further help readers to establish a link between the fate of the merchant-ship Tyre and that of the sanctuary of Jerusalem.

${ }^{120}$ See, e.g., B.F. Batto, Slaying the Dragon: Mythmaking in the Biblical Tradition (Louisville, KY: W/JKP, 1992), 94-97. A good survey of various approaches to Ezk. 28 can be found in R.R. Wilson, 'The Death of the King of Tyre: The Editorial History of Ezekiel 28', in J.H. Marks and R.M. Good (eds.), Love \& Death in the Ancient Near East: Essays in Honor of Marvin H. Pope (Guilford, CT: Four Quarters, 1987), 211-18. Wilson correctly observes that imagery related to the Israelite high priest is used in 28:11-19 and concludes from this that an ostensibly Tyrian oracle was originally addressed against the Jerusalemite priesthood. Yet the primeval human in Genesis has priestly features as well (see G.J. Wenham, 'Sanctuary Symbolism in the Garden of Eden Story', PWCJS 9 [1986], 19-25). Thus the oracle may feature characteristics of the Israelite high priest because it alludes to the primeval human who, in Israelite tradition, is like a priest.

${ }^{121} \mathrm{~L}$. Boadt argues that here and in the oracles against Pharaoh 'the hollowness of the myth of divine royal status' is revealed ('Rhetorical Strategies in Ezekiel's Oracles of Judgment', in J. Lust [ed.], Ezekiel and His Book [Leuven: Leuven University Press, 1986], 182-200, esp. pp. 198-99); cf. W. Zimmerli, Ezekiel 2: A Commentary on the Book of the Prophet Ezekiel, Chapters 25-48 (Philadelphia: Fortress, 1983), 78; W. Eichrodt, Ezekiel: A Commentary (London: SCM Press, 1970), 390-91. Yet, all but three of the prophecies 
prophecy against Sidon (28:20-24) is appended to the collection of oracles against Tyre. It links Sidon with the nations condemned in ch. 25 for their malice against Israel (note 28:24). The threefold use of the recognition formula in this prophecy (vv. 22b, 23b, 24b) signals that it concludes the first half of the oracles against other nations. 122 The second half of the collection is devoted to a series of oracles against Egypt (chs. 29-32), one of which (29:17-21) bears the latest date of the book (April 26, 571) and responds to Nebuchadrezzar's failure to take spoils from Tyre by promising him spoils from Egypt instead.

\section{The problem of unfulfilled prophecy in Ezekiel's oracles against Tyre}

The discussion whether Ezekiel's announcement of what would happen to Tyre was fulfilled or not deserves more space than is given here. Fortunately, the problem has been discussed before and it will be sufficient to summarise the main points, as they relate to this paper. ${ }^{123}$ The key issue is whether Ezekiel expected that Nebuchadrezzar would utterly destroy the city of Tyre as a plain reading of Ezekiel 26:7-14 might suggest. Two arguments have been brought forward against such a reading. Firstly, it is pointed out that the language is stereotypical and hyperbolic and thus a literal

concerning Egypt have the pharaoh as their explicit addressee who seems to represent Egypt as a whole (cf. 29:2). The same is probably true here. Since however the book of Ezekiel exhibits strong reservations about the monarchy, it cannot be entirely ruled out that the pretensions of absolute kingship are under attack here.

$122 \mathrm{Cf}$. Zimmerli's remarks with regard to 28:20-23(24): 'The only thing that emerges as clearly defined is the statement about Yahweh's self-glorification in that event. This, however, obviously indicates a final, heightened résumé of all the preceding judgments passed on the nations. The oracle against Sidon is a concluding oracle, added in order to bring out the theological statement with which the oracles against foreign nations are really concerned' (Ezekiel 2, 99). 28:25-26 forms the centre of the collection of oracles concerning foreign nations.

${ }^{123}$ Note D. Thompson, 'A Problem of Unfulfilled Prophecy in Ezekiel: The Destruction of Tyre (Ezekiel 26:1-14 and 29:18-20)', Wesleyan Theological Journal 16/1 (1981), 93-106; A.S. Lawhead, 'A Problem of Unfulfilled Prophecy in Ezekiel: A Response', Wesleyan Theological Journal 16/2 (1981), 15-19. See also Block, Ezekiel 25-48, 147-49. 
fulfilment was not to be expected. ${ }^{124}$ Secondly, it is questioned whether the passage refers exclusively to Nebuchadrezzar. ${ }^{125}$

Regarding the first argument, it is certainly true that the stereotypical language used in vv. 8-11 to describe the fall of Tyre as if it were a mainland city suggests that the prophecy did not aim at giving an exact description of future events. ${ }^{126}$ Nevertheless, these verses seem to envisage complete success for the invader. ${ }^{127}$ The prophecy proved true in the long run in so far as Phoenicia remained under Babylonian control from then onwards until the rise of the Persian empire and in so far as Tyre's glory as the commercial centre of the ancient world was seriously damaged and never fully restored. Yet in the months immediately following the end of the siege it was not clear how successful Nebuchadrezzar had been and while the length of the siege was remarkable, its outcome was fairly conventional in the context of Tyre's history and thus unlike what Ezekiel's prophecy might have led him and his audience to believe.

In support of the view that the prophecy did not refer to Nebuchadrezzar's campaign alone, two basic arguments have been brought forward, one to do with changes of person in the oracle, the other with the general nature of prophecy. 128 Having explicitly identified Nebuchadrezzar as God's instrument in v. 7, ch. 26

124 E.g., Lawhead, 'Problem', 16-17; cf. the general statements made by A.B. Davidson, The Book of Ezekiel (Cambridge: CUP, 1896), 208, and quoted by Lawhead, 'Problem', 19.

125 E.g., J.B. Payne, Encyclopedia of Biblical Prophecy: The Complete Guide to Scriptural Predictions and Their Fulfillment (Grand Rapids, MI: Baker Books, 1980), 362-63, relates Ezk. 26:1-4a, 6-11; 28:6-11, 16-19 to the siege of Tyre by Nebuchadrezzar, and 26:4b-5, 12-21; 27:1-2, 26-32, 34-36 to the collapse of Tyre under Alexander.

${ }^{126}$ See e.g. W. Eichrodt, Ezekiel, 371; Zimmerli, Ezekiel 2, 36-37; F. Fechter, Bewältigung der Katastrophe: Untersuchung zu ausgewählten Fremdvölkersprüchen im Ezechielbuch (Berlin: de Gruyter, 1992), 92.

${ }^{127}$ See Block, Ezekiel 25-48, 41. A number of commentators in the past sought to relate the verses to Ushu (mainland Tyre) which was destroyed by Nebuchadrezzar as it had been often before, e.g. J. Urquhart, Wonders of Prophecy (London: Pickering \& Inglis, 1939), 12-14. Yet 26:6, 8 make a clear distinction between Tyre itself and its daughter cities and there can be no doubt that the prophets had the island-city in mind when they spoke of 'Tyre'.

128 Thompson, 'Problem', 95-96, thinks that Adam Clarke in the nineteenth century was probably the first to introduce Alexander into the equation, noting that Jerome, Luther, and Matthew Poole among others read the entire passage as referring to Nebuchadrezzar's campaign. It is not clear to me whether Clarke paid attention to the changes of person. Payne's suggestion that the first half of v. 4 refers to Nebuchadrezzar and the second half to Alexander (see above) should be discussed under the aspect of 'telescoping' as a general feature of prophecy, as there is no clue to such a division in the text itself. 
continues with third person masculine references to describe Nebuchadrezzar's work in vv. 8-11. In v. 12 the prophecy switches to the third person plural and in v. 13 to the first person singular referring to Yahweh. Does this indicate that the plundering of the conquered city (v. 12), or the silencing of Tyre's music (v. 13) and the reduction of the merchant-city to a 'bare rock' (v. 14, cf. צ' in v. 4) will take place at some other time? The change of person from $v$. 11 to v. 12 seems to have been regarded as infelicitous by some even in antiquity, as can be seen from the fact that most LXX manuscripts read the singular in v. 12 as well. Yet Fechter points out that while vv. 8-11 speak about a military-tactical action, v. 12 relates to the common practice among victorious combatants of plundering cities or settlements as 'remuneration' for their efforts and therefore properly switches to the plural. ${ }^{129}$ The change to statements in the first person about what Yahweh himself will do is not very surprising either, given that the emphasis throughout the prophecies in Ezekiel is on God's doing. Vv. 13-14 do not introduce a new actor but underline Yahweh's involvement in Nebuchadrezzar's campaign. 130 In any case, if there is a problem of unfulfilled prophecy, it is not solved by such manoeuvres, as even vv. 8-11 alone (without vv. 1214) do not seem to be an accurate description of Nebuchadrezzar's siege and when Tyre was destroyed two and a half centuries later, it was soon rebuilt.

The second argument brought forward against a 'plain' reading of the text as referring to Nebuchadrezzar only does not necessarily require any clues in the text, although sometimes the change of persons is used as supporting argument. It is an argument from the nature of prophecy and is based on the assumption that a (predictive) prophecy can be understood fully only in the light of its fulfilment, which might reveal that different parts of the prediction referred to different events. Thompson comments on Payne's application of the principle to Ezekiel 26, 'Such a treatment requires a fragmentation of the text and an overly technical reading of it which Ezekiel's first hearers/readers would likely not have understood or perhaps even thought of.' 131 He is of course right and probably understates his point. Yet commentators who adopt this approach do not claim that the prophet's audience or even the prophet himself

${ }^{129}$ Fechter, Bewältigung, 90.

130 Overall, of course, it might be more appropriate to speak of Nebuchadrezzar's involvement in Yahweh's campaign.

131 Thompson, 'Problem', 97. 
knew precisely what he was talking about or the time when it was going to happen. The prophet could see several events that in reality would happen at quite some temporal distance from each other merged into one picture. This is often called 'prophetic telescoping'. Payne explains it as follows: 'Biblical prophecy may leap from one prominent peak in predictive topography to another, without notice of the valley between, which may involve considerable lapse in chronology.'132 At its best, this recognises that biblical prophecy predicts what will happen in the more imminent future not as an isolated event, but as a pledge of the fulfilment of God's ultimate purpose. At its worst, the application of this principle destroys the unity of a pronouncement and with it the continuity of communication. If the human author and audience thought that Nebuchadrezzar would destroy Tyre, but the divinely intended meaning was that Alexander would accomplish this feat, then the divine intention does not merely transcend the human author's intention, but flatly contradicts it as far as the question whether Nebuchadrezzar would or would not conquer Tyre is concerned.133 It would seem that in this particular instance, what some call a failure of prophecy has been traded against a failure of communication.

It is concluded that the prophecy was not fulfilled in the way Ezekiel and his audience would have naturally expected it to be fulfilled, yet the 'failure' of the prophetic word was not as dramatic as is often claimed. The net results of Nebuchadrezzar's campaign were his control over the Levant and the end of Tyre's commercial predominance. While Tyre and Babylon must have come to some sort of understanding, in the final analysis Tyre was the loser, as has been pointed out in the review of Tyre's history above. There is no need and no good reason for claiming with Eichrodt 'the sovereign freedom of God to fulfil a prediction of a prophet in whatever way seems good to him'. ${ }^{134}$ Not without some justification, Carroll wonders at the theologians who 'in preserving the freedom of God to be God...have come perilously close to installing Humpty Dumpty

132 Payne, Encyclopedia, 137.

133 E.W. Hengstenberg, De rebus Tyriorum: commentatio academica (Berlin: Oehmigke, 1832), argued that Nebuchadrezzar was in fact able to conquer Tyre, but even he acknowledged that there were elements of the prophecy that remained unfulfilled with Nebuchadrezzar for which he resorted to the principle of 'telescoping'.

${ }^{134}$ Eichrodt, Ezekiel, 410 . However he is right in emphasising that the prophets were concerned with God's plan to which single historical events were subordinated. 
("a word means what I choose it to mean") as his prophet'.135 Eichrodt does not give sufficient weight to the characteristic portrayal of God in the Bible as a God who is responsive and faithful in relationships with humans, as well as sovereign and free. ${ }^{136}$

Ezekiel 29:17-21 is often interpreted to indicate that Ezekiel admitted that his predictions against Tyre did not come to pass. The oracle is certainly a reaction to Nebuchadrezzar's failure to spoil Tyre as even the date (the latest in the book) indicates. Yet there is no explicit admission of failure. As Dewey Beegle put it, 'Ezekiel didn't say, "Sorry, folks, I made a mistake."'137 Verses 17-20 can be read as simply a comment upon the fact that Nebuchadrezzar did not get as much out of Tyre as he deserved, whether this was because he did not succeed in conquering Tyre or because Tyre had already evacuated all its wealth. ${ }^{138}$ Yet this in itself is in contradiction to the expectation expressed in ch. 26.139 Such a contradiction is not necessarily an indication of the 'failure' of the prophetic word if the contradiction can be explained satisfactorily. Thus a number of commentators appeal to the conditional nature of biblical prophecy to explain this contradiction. Ellison suggests, 'Something will have happened both in Tyre and in Egypt, and it may be in Babylon, to

135 R.P. Carroll, When Prophecy Failed: Reactions and Responses to Failure in the Old Testament Prophetic Traditions (London: SCM Press, 1979), 176.

136 See R.W.L. Moberly, 'God Is Not a Human That He Should Repent? (Numbers 23:19 and 1 Samuel 15:29)', in T. Linafelt and T.K. Beal, God in the Fray: A Tribute to Walter Brueggemann (Minneapolis: Fortress Press, 1998), 112-23.

137 D.M. Beegle, Prophecy and Prediction (Ann Arbor, MI: Pryor Pettengill, 1978), 50. In his view, Ezekiel 'simply issued a revised prediction in the name of Yahweh' (ibid.). Ezk. 29:17-21 is however more appropriately described as supplementary prediction.

138 The latter suggestion was made by Aphrahat and Jerome and has been revived by S. Smith, 'The Ship Tyre', PEQ 85 (1953), 104-109, who sees an indication of this in Ezk. 27:27. Lack of evidence for Nebuchadrezzar's conquest of Tyre suggests the former option, as it is unlikely that a significant event such as the destruction of Tyre would have been left unrecorded even in the sources uncovered so far.

${ }^{139} \mathrm{Cf}$. 'to him and to his army' (29:18) with the plural in $26: 12$. To remove this contradiction, R. Meier Leibush Malbim (1809-1879) suggested that Nebuchadrezzar destroyed Tyre and gathered the spoils, but as he prepared to demolish the city completely, the island was inundated with water, the spoils were lost and Tyre became a 'smooth rock' with all its earth swept away (A.J. Rosenberg, The Book of Ezekiel: Translation of Text, Rashi. and Commentary [2 vols.; New York: Judaica Press, 1991], 2:221). To the objection that Tyre was rebuilt, he responded with the claim that this was not on its original site, an answer apparently already given by R. David Kimchi (Rosenberg, Ezekiel, $2: 223-24)$. 
cause the doom uttered not to go into effect, and for Ezekiel this was so obvious that neither apology nor explanation was necessary.'140 Yet v. $21 \mathrm{~b}$ reveals that the failure of Nebuchadrezzar's troops to return to Babylon with great profit had called into question the credibility of Ezekiel's prophetic words. ${ }^{141}$ Although a literal fulfilment was hardly expected and the failure of the prophecy to materialise in every detail was therefore not a real problem, Nebuchadrezzar's failure to conquer Tyre cast doubt on Yahweh's power to accomplish his purpose of fundamentally changing the political and economic situation of the nations or on Ezekiel's ability to describe Yahweh's purpose accurately. If Egypt would be unable to resist Nebuchadrezzar, Ezekiel's prophecy would be vindicated and the limited nature of the Babylonian king's success with Tyre would be seen for what it was, a temporary setback. On that day, Ezekiel's audience could also be assured again of Yahweh's plan as expressed in the promises of Israel's renewal and restoration (v. 21a). Apparently, Nebuchadrezzar's success in Egypt was not clear-cut either. ${ }^{142}$ Yet the main point of Ezekiel's pronouncements against Egypt was fulfilled in that Egypt became a 'lowly kingdom' that could no longer threaten Yahweh's position as a source of trust for Israel (29:14-16). ${ }^{143}$ Lawrence Boadt is partly right when he summarises:

Ezekiel can blithely predict the worst for Tyre or Egypt, but sees success enough if God exercises judgment against their pride in any noticeable dramatic manner. Ezekiel chooses his images not because he expects them to happen in just such a way, but because they are drawn from the common experience of the horrors of sieges, devastations, etc., and form expressive models which can be couched in the consecrated language of tradition. ${ }^{144}$

140 H.L. Ellison, Ezekiel: The Man and His Message (London: Paternoster Press, 1956), 103. Cf. A. Cody, Ezekiel with an Excursus on Old Testament Priesthood (Old Testament Message 11; Wilmington, DE: Glazier, 1984), 144. ${ }^{141}$ Cf. Block, Ezekiel 25-48, 152-53.

142 See Y.H. Katzenstein, 'Nebuchadnezzar's Wars with Egypt', Eretz-Israel 24 (1993), 184-86 [Hebrew; English summary on p. 238*]; cf. Wiseman, Nebuchadrezzar, 39-41; A. Gardiner, Egypt of the Pharaohs: An Introduction (Oxford: Clarendon Press, 1961), 360-63.

143 Cf. J.B. Taylor, Ezekiel: An Introduction and Commentary (TOTC 20; Leicester: IVP, 1969), 200.

${ }^{144}$ L. Boadt, Ezekiel's Oracles against Egypt: A Literary and Philological Study of Ezekiel 29-32 (BibOr 37; Rome: Biblical Institute Press, 1980), 53. He continues: 'This technique hardly to be taken literally point for point, is wellillustrated by the lists of unfulfilled prophecies which critics have collected from the major prophets, the majority of which involve military imagery'. Boadt still calls Ezk. 29:17-21 an 'apologia'. 


\section{Isaiah, Ezekiel and the future of Tyre}

If the prophets were concerned as much or more with God's plan and purpose than with specific events, it might be helpful to distinguish elements of promise and prediction in prophetic oracles. The promise in Ezekiel 26 is that God will not tolerate (commercially motivated) glee over the fall of his people and that he will make an end to selfcentred trade. The prediction is that Nebuchadrezzar would spoil Tyre, which will become a 'bare rock' never again to be rebuilt. Both the promise and the prediction came true only partially. As for the prediction, Nebuchadrezzar's troops did not spoil Tyre and the city did not become a 'bare rock', but the Babylonian king was able to break Tyre's resistance and Tyre's commercial predominance was never again the same. As for the promise, it found a fulfilment in that the fall of Jerusalem did not pay off for Tyre and its trade was never to be the same. Yet the final fulfilment of the promise is still outstanding as long as cities and nations get away with disregarding God's people and with self-centred trade. For those who trust God, the partial fulfilment of the prediction is a pledge that the promise will come true. For those who are suspicious of God's power or reliability, or even doubt his existence, the partialness of the fulfilment is a sign of the foolishness of trust in God. The way we respond to the prophetic word and its partial fulfilment/nonfulfilment is directly related to our experience of God or lack thereof. As long as God's righteousness and faithfulness are not yet fully vindicated, the apologetic value of prophecy will be limited. There is enough fulfilment to comfort and encourage the believer but not sufficient to force the unbeliever to recognise God's power and faithfulness.

A comparison of the promise that underlies Isaiah's oracle against Tyre with that which underlies Ezekiel's prophecy against Tyre is particularly relevant for those who trust that Isaiah and Ezekiel gave us a true glimpse of God's purpose. Even if the predictions did not address the same historical situation, although most older commentators thought they did, ${ }^{145}$ the underlying promise seems to be different. In Ezekiel, a complete end is

145 E.g. J. Calvin, Commentary on the Book of the Prophecies of Isaiah, Vols. 1 \& 2 (Isaiah 1-32) (Grand Rapids, MI: Baker Book House, 1984), 2:143-44; J.A. Alexander, Commentary on the Prophecies of Isaiah, Two Volumes in One (Grand Rapids, MI: Zondervan, 1953; reprint of the revised edition of 1875), 1:392-93; C.F. Keil and F. Delitzsch, Commentary on the Old Testament (10 vols.; Grand Rapids, MI: Eerdmans, 1986), Delitzsch in vol. 7 on Isaiah (1:41421; see also the bibliographic reference above) and Keil in vol. 9 (1:417-25). 
anticipated for Tyre's trade, in Isaiah Tyre is restored to its former trading glory. It is possible to subordinate Isaiah's prophecy to that of Ezekiel and to argue that Tyre would be destroyed and restored after 'seventy years', understood literally or figuratively, before it was to be destroyed again to become a 'bare rock'.146 Yet can there be a solution that gives full weight to both pronouncements?

Such a solution might be suggested by Zechariah 9:2b-4. The passage affirms with Ezekiel and with words borrowed from Amos that Tyre will be destroyed. Yet if Meyers and Meyers are correct, Zechariah 9:1-8 promise the restoration of 'the land that had been pledged to the twelve tribes of Israel' including territories that were never actually in Israel's possession. ${ }^{147}$ They note that the delineation of Israel's boundaries in Ezekiel 47 includes the Phoenician territory (v. 20). ${ }^{148}$ Thus the inclusion of Tyre and Sidon in Israel's territory, only implicit in Ezekiel, is made explicit in Zechariah. In this way, the socio-economic significance of Tyre could be preserved. The pronouncements made by Isaiah and Ezekiel can then be read as complementary, both affirming that God makes a complete end to Tyre's self-centred trade and that ultimately all commercial activity will serve God and his people. The perspective from the book of Zechariah suggests a re-lecture of Isaiah 23 with a more positive assessment of Tyre's trade. The lack of reference to prostitution in the Targum and the LXX of 26:17 might help such a reading.

Such a positive reading of Tyre as commerce for the benefit of God's people must stand alongside a negative reading of Tyre as a symbol for idolatrous trade. It was already hinted that 'John's great oracle against Babylon (18:1-19:8) echoes every one of the oracles against Babylon in the Old Testament prophets, as well as the two major oracles against Tyre.'149 Thus the seer uses oracles against Tyre together with oracles against Babylon to announce God's judgement on the military, political and economic power of his time. Worship of the one true God will always have to expose political, social and economic idolatries, and the pronouncements against Tyre will continue to be of help for doing just that. Tyre in so far as it

\footnotetext{
${ }^{146}$ A further complication arises when the 'seventy years' itself are seen to be fulfilled several times; see Delitzsch, Isaiah, 1:420-21.

${ }^{147}$ Meyers and Meyers, Zechariah 9-14, 162; see pp. 162-69 for the development of the argument.

148 Meyers and Meyers, Zechariah 9-14, 165.

${ }^{149}$ Bauckham, Theology, 5.
} 
evokes commerce can be redeemed; in so far as it evokes idolatrous trade, however, it stands condemned. ${ }^{150}$

\section{Conclusions}

Biblical prophecy contains more prediction than is granted sometimes. However, the prophetic focus is not on the ability 10 present a precise outline of the future but on the proclamation of God's purpose. It is because God responds to evil perpetrated and because he has a plan for his people and for the whole world that the prophetic word has to speak about the future. Mickelsen rightly emphasised that prophecy is neither 'a more vivid way of writing history after the event has occurred' nor 'simply history written beforehand'.151 Prophecy does not gives us a picture of events similar to a historian's account. Neither did the prophets utter mere platitudes or general hopes about what the future might bring. Yet how is the insight that prophecies are concerned with describing God's purpose rather than with outlining the precise details of future events related to the fact that specific events seem to be referred to? The answer is often given with reference to the principle of 'prophetic telescoping' according to which the prophet saw compressed in one picture a panorama of events that would develop in history in several stages. This approach has been referred to in the discussion of Ezekiel 26. Yet the principle has been applied to Isaiah 23 as well. Thus von Orelli claimed that 'the prophetic gaze sees together in one picture what was realized in history gradatim' referring to campaigns against Tyre from the eighth century $\mathrm{BC}$ (Shalmaneser V) to the thirteenth century AD (crusaders). 152 To some this makes the prediction all the more remarkable, yet it seems

${ }^{150}$ Note that the redemption of civilisation is also found in Revelation; see Bauckham, Theology, 126-43, on the New Jerusalem.

151 A.B. Mickelsen, Interpreting the Bible: A Book of Basic Principles for Understanding the Scriptures (Grand Rapids, MI: Eerdmans, 1963), 289. See already P. Fairbairn, The Interpretation of Prophecy (2nd edition; Edinburgh: T. \& T. Clark, 1865), 83-109.

152 Von Orelli, Prophecies of Isaiah, 139. The fall of Tyre in AD 1291 was a significant point in its history, but Tyre had lost its economic predominance long before and is today again 'a booming, bustling, sprawling town' $(\mathrm{H}$. Seeden, 'Tyre Summer 1990: An Eyewitness Report', in Joukowsky, Heritage, 127-30, esp. p. 129). Given the revival of Tyre in the twentieth century, von Orelli might have to consider a further campaign against Tyre in the future if he were alive today. 
to me that to allow any event over the span of two millennia to contribute to the fulfilment of a prediction makes it rather less remarkable, as a fulfilment in the future can be claimed for every detail that has not (yet) been fulfilled. It certainly makes the prophecy less coherent. I want to suggest that to speak of multiple fulfilment rather than a panorama of fulfilment is more appropriate.

In contrast to the panorama view of prophecy in which different parts of an oracle are allocated to different periods, the multiple fulfilment view preserves the integrity of an oracle as an act of communication, while taking into account the most significant feature of biblical prophecy that gave rise to the panorama view. Richard Bauckham expressed it like this:

Biblical prophecy always both addressed the prophet's contemporaries about their own present and the future immediately impending for them and raised hopes which proved able to transcend their immediate relevance to the prophet's contemporaries and to continue to direct later readers to God's purpose for their future. ${ }^{153}$

In other words, a certain element of non-fulfilment is characteristic for biblical prophecy and is an indication that biblical prophecy usually expresses God's larger plan as well as his purpose for a specific situation. Even a prophecy that has been fulfilled remains open for further fulfilment. ${ }^{154}$ This possibility of reinterpreting and reapplying prophecies is given because God's purposes in history are consistent and his past acts can serve as models for the future. The use of oracles against Tyre in the book of Revelation suggests that they might be better applied to current economic empires than to present-day Tyre.

In some respects, the view of prophecy presented here is similar to the panorama view of prophecy. Yet some of the underlying principles are different. The concept of God intending more with the whole of a pronouncement should be distinguished from the idea that God would apply different parts of the oracle to different situations. ${ }^{155}$ The panorama view of prophecy is much closer to the

153 Bauckham, Theology, 152.

${ }^{154}$ Note in particular Ezk. 38:17; see D.I. Block, 'Gog in Prophetic Tradition: A New Look at Ezekiel XXXVIII 17', VT 42 (1992), 154-72. Similarly, the author of Daniel 9 was hardly unaware of the fulfilment of Jerusalem's seventy year desolation in the Babylonian period (605/597-539 BC or 586-5 16 BC), yet apparently felt that the prophecy was not 'fully fulfilled'.

155 1 Pet. 1:10-11 should not be used as justification for parcelling out different verses to different historical eras. The apostle seems to be doing precisely the opposite in suggesting that all the varied prophecies find their focal point in Christ (cf. 2 Cor. 1:20). 
strictly literal style of interpretation which interprets the predictive element of prophecy as prognostication of isolated future events rather than proclamation of God's purpose. Such readings often violate the spirit of a prophecy for the sake of its letter when it comes to prophecies of punishment. Prophecies of punishment require a more immediate fulfilment as they are a response to a specific situation. If the fulfilment of Joel's word against Tyre and Sidon took place 'during the crusades when the moors took Tyre and sold the inhabitants', 156 the relationship between crime and punishment is completely severed. In such an interpretation, the accidental relationship of a crime committed in one town and a 'punishment' meted out in the same town more than two thousand years later is given more significance than the relationship between punishment and crime itself. 157 This is surely not right. By its closeness to such readings, the principle of 'telescoping' is in danger of obscuring the relationship between the situation to which God reacts according to the prophetic word and the reaction itself. Positively, it can be said that the panorama view often preserves the eschatological tendency of biblical prophecies, even where it does not acknowledge the source of this eschatological tendency in the tension created by the partial non-fulfilment of the prophetic promise. ${ }^{158}$

A further conclusion needs to be drawn regarding the use of prophetic predictions in apologetics. The apologetic approach that puts Ezekiel's prediction of Tyre becoming 'a bare rock' and 'a place for spreading nets' (26:4-5) next to a photograph of some of the ruins of Tyre and a lonely fisherman as proof for the reliability of God's word is not only disingenuous, ${ }^{159}$ but also the product of a misunderstanding of the nature of predictive prophecy. Prophetic prediction is not a strange way of historiography, but proclamation of God's purpose. It is therefore not primarily a matter of attempting to relate details of the text to details of history. A focus on present-

\footnotetext{
156 So Sharif George, http://www.sharif.co.uk/tyre.html [accessed 03/07/99].

157 George dates Joel to $800 \mathrm{BC}$. For a critique of similar readings of prophecies against Edom, see Fairbairn, Interpretation, 219-25. It seems to me that evangelical commentators over a hundred years ago (Fairbairn, Edersheim, Hengstenberg) espoused a more organic view of prophecy than some of their successors who use the telescope analogy more mechanically.

${ }^{158}$ Bauckham uses the felicitous phrase 'excess of promise over fulfilment', e.g. Theology, 156.

159 It is disingenuous because the photograph has to be carefully shot to avoid glimpses of modern Tyre. For impressions of contemporary Tyre see E.C. Carella, 'Glimpses of Tyre in 1984', in Joukowsky, Heritage, 87-110, and H. Seeden, 'Tyre Summer 1990'.
} 
day Tyre easily ignores the comfort and challenge prophetic predictions give by virtue of being expressions of God's purpose. What Bauckham says about Babylon in the book of Revelation also applies to the prophecies examined in this paper: 'Any society whom Babylon's cap fits must wear it. Any society which absolutizes its own economic prosperity at the expense of others comes under Babylon's condemnation.' 160 The promise that Tyre would become a 'bare rock...a place for spreading nets' has found a fulfilment in the end of Tyre's trading empire and the apologetic value of the prophecies against Tyre lies in the fact that God can be shown to have worked consistently with this purpose in mind. But the promise will be truly fulfilled only in the coming of God's kingdom, which makes an end to all forms of idolatry.

${ }^{160}$ Bauckham, Prophecy, 156. Cf. the chapter on Revelation 18 in his The Bible in Politics: How To Read the Bible Politically (London: SPCK and Louisville, KY: W/JKP, 1989). 